\title{
Ancoragem esquelética em Ortodontia com miniimplantes
}

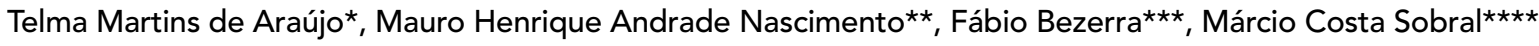

\begin{abstract}
Resumo
A utilização de dispositivos transitórios de ancoragem, como coadjuvante no tratamento ortodôntico, tem demonstrado, nos últimos anos, alta versatilidade de aplicação clínica, principalmente no que tange o uso dos miniimplantes. Estes aparatos surgem como alternativa para os casos em que a ancoragem se torna fator crítico para o sucesso do tratamento ortodôntico. Neste artigo, buscamos uma abordagem ampla do tema, incluindo: locais de instalação, procedimentos cirúrgicos, indicações, cuidados com a higiene e complicações mais freqüentes na utilização dos miniimplantes.
\end{abstract}

Palavras-chave: Miniimplantes. Microparafusos. Ancoragem. Ortodontia.

\section{INTRODUÇÃO}

A ancoragem ortodôntica tem sido motivo de preocupação para os ortodontistas desde os primórdios da especialidade. Uma terapia ortodôntica bem sucedida, na grande maioria das vezes, depende de planejamento criterioso da ancoragem, não sendo exagero afirmar que este fator é um dos determinantes quanto ao sucesso ou insucesso de muitos tratamentos.

As diversas formas de ancoragem descritas na literatura, como barra-lingual e transpalatina, botão de Nance, elásticos intermaxilares e aparelho extrabucal, apesar de eficientes em muitos casos, permitem certo grau de movimentação da unidade de ancoragem ou são dependentes da colaboração do paciente. Sendo que, para o tratamento de más oclusões mais severas, otimização de re- sultados com mecânicas mais simples ou, ainda, diminuição do tempo de tratamento, atualmente, o ortodontista pode lançar mão de dispositivos transitórios de ancoragem esquelética.

Com a utilização dos implantes, surge um novo conceito de ancoragem em Ortodontia, denominado ancoragem esquelética, a qual não permite a movimentação da unidade de reação. Ela é obtida devido à incapacidade de movimentação da unidade de ancoragem frente à mecânica ortodôntica ${ }^{55}$. As cargas ortodônticas de natureza contínua, unidirecional e de baixa magnitude não são capazes de gerar atividade osteolítica na interface óssea do implante, sendo que a ausência de movimentação nestes aparatos permite maior previsibilidade de tratamentos complexos, independente da cooperação do paciente ${ }^{7,32,34,61}$.

\footnotetext{
* Doutora e Mestre em Ortodontia pela UFRJ. Professora Titular da FO.UFBA. Coordenadora do Curso de Especialização em Ortodontia - FO.UFBA. Diretora do Board Brasileiro de Ortodontia e Ortopedia Facial.

** Aluno do Curso de Especialização do Centro de Ortodontia e Ortopedia Facial Professor José Édimo Soares Martins - FO.UFBA

*** Professor do Curso de Especialização em Implantodontia da ABO-Bahia.

**** Mestre em Ortodontia pela UFRJ. Professor do Curso de Especialização do Centro de Ortodontia e Ortopedia Facial Professor José Édimo Soares Martins - FO.UFBA
} 
A ancoragem esquelética absoluta teve início com a utilização de implantes com finalidade protética $^{1,24,51,52,58}$, os quais, apesar de bastante eficientes nesta função, possuem restrições à sua utilização, devido ao seu tamanho e complexidade cirúrgica para inserção e remoção, quando estes não são utilizados como parte de uma reabilitação protética ${ }^{20}$. Outros sistemas de ancoragem como os Onplants (Nobel Biocare, Gotemburgo, Suécia) e o Orthosystem (Straumann Institute, Waldemburg, Suíça) foram criados tentando suprir esta necessidade dos ortodontistas ${ }^{5,13,19,25,62}$. Porém, por serem de difícil utilização e alto custo, não ganharam muita popularidade no meio ortodôntico.

As mini-placas de titânio, originalmente utilizadas para fixação cirúrgica, apesar de se prestarem bem como recurso de ancoragem absoluta, possuem algumas limitações quanto aos locais de fixação, além de apresentarem maior morbidade cirúrgica devido à necessidade de realização de dois procedimentos operatórios (instalação e remoção), e elevado custo devido à complexidade técnica ${ }^{11,14,15,16,17,18,38,54,56,59}$.

$\mathrm{Na}$ busca por um recurso de ancoragem esquelética mais versátil, percebeu-se que os parafusos para fixação cirúrgica, apesar de seu tamanho reduzido, possuíam resistência suficiente para suportar a maioria das forças ortodônticas. O inconveniente deste tipo de parafuso residia na dificuldade de se acoplar acessórios ortodônticos à cabeça do mesmo, além de não permitirem boa acomodação dos tecidos moles adjacentes. Baseado nesta idéia, foram desenvolvidos os miniimplantes específicos para Ortodontia, sendo estes, dentre todos os implantes temporários, os que melhor se adequam às características necessárias a este tipo de ancoragem $^{4,20,37}$.

A eficiência da ancoragem ortodôntica, conseguida através dos implantes, tem sido bem demonstrada na literatura. Para terem boa aceitação por parte dos pacientes e serem idealmente utilizados com esta finalidade, os implantes preci- sam diferir daqueles utilizados em reabilitações protéticas, devendo apresentar as seguintes características: tamanho reduzido; fácil colocação; resistência às forças ortodônticas; capacidade de receber carga imediata; utilização com as diversas mecânicas ortodônticas; fácil remoção e baixo custo $^{20,23,26,39,41,53,60}$.

Neste artigo, os autores se propõem a expor, baseando-se em experiências clínicas e publicações científicas, diversos aspectos referentes aos miniimplantes ortodônticos. Dentre eles: suas principais características, critérios de seleção, procedimento cirúrgico, tipos de movimentação ortodôntica a que se aplicam, associando a função específica aos respectivos locais de inserção para otimizar sua utilização, remoção e principais problemas e dificuldades em sua utilização.

\section{NOMENCLATURA}

A utilização de dispositivos ortodônticos para ancoragem esquelética com diferentes desenhos, formas e metodologias de aplicação tem se mostrado cada vez mais freqüente clinicamente, assim como sua referenciação em periódicos especializados. Da mesma forma, diferentes termos como miniimplantes, miniimplantes ortodônticos, microimplantes, microimplantes ortodônticos, miniparafusos e microparafusos têm sido utilizados pelos autores em diferentes publicações, gerando a necessidade de padronização quanto à terminologia mais adequada para se referir a dispositivos específicos.

Em 2005, Mah e Bergstrand ${ }^{36}$ publicaram os resultados compilados e obtidos através de reunião, realizada no ano anterior, envolvendo diversos pesquisadores e clínicos experientes na área de ancoragem esquelética, previamente à reunião da AAO (American Association of Orthodontics), em Orlando. Um dos tópicos abordados neste encontro foi a definição da melhor nomenclatura a ser utilizada para estes dispositivos, sendo que o termo Dispositivo de Ancoragem Temporária (DAT) refere-se a "todas as variações de implan- 
tes, parafusos, pinos e onplants que são instalados especificamente para promover ancoragem ortodôntica e são removidos após a terapia biomecânica", o que foi aceito pelos presentes. Da mesma forma, apesar de não haver consenso do ponto de vista científico, o termo miniimplante parece ser mais adequado do que microimplante, uma vez que "micro" é definido como $10^{-6}$. O desenho e a forma destes sistemas de ancoragem podem sugerir o termo parafuso como adequado, mas para evitar conotações negativas, os autores reunidos demonstraram a preferência por palavras como pinos, implantes ou dispositivos.

\section{CARACTERÍSTICAS}

Existe, atualmente, disponível no mercado nacional e internacional uma série de DATs com diferentes desenhos, diâmetros, comprimentos, graus de pureza do titânio e tratamentos de superfície. Com o intuito de tornar didáticas suas principais características e critérios de seleção, utilizaremos uma classificação geral e não restrita a detalhes, muitas vezes de apelo mais comercial que científico.

Tido como um dos maiores avanços da Ortodontia contemporânea, e sendo alvo de grande atenção em trabalhos recentes, os miniimplantes ortodônticos são fabricados em titânio com diferentes graus de pureza e tratamento de superfície, podendo variar entre 4 a $12 \mathrm{~mm}$ de comprimento por 1,2 a $2 \mathrm{~mm}$ de diâmetro ${ }^{41,50,53}$ (Fig. 1). Apesar dos diferentes desenhos, formas e medidas, que variam de acordo com a marca comercial, é possível dividirmos a constituição dos miniimplantes em três partes distintas: A) cabeça, B) perfil transmucoso e C) ponta ativa ${ }^{4,41}$ (Fig. 2).

A cabeça do implante é a parte que ficará exposta clinicamente e será a área de acoplamento dos dispositivos ortodônticos, como elásticos, molas ou fios de amarrilho. Também sofre variação dependendo do fabricante, mas como regra geral possui uma canaleta circunferencial e uma perfuração transversal que viabilizam a ativação ortodôntica ${ }^{4,7}$ (Fig. 3).

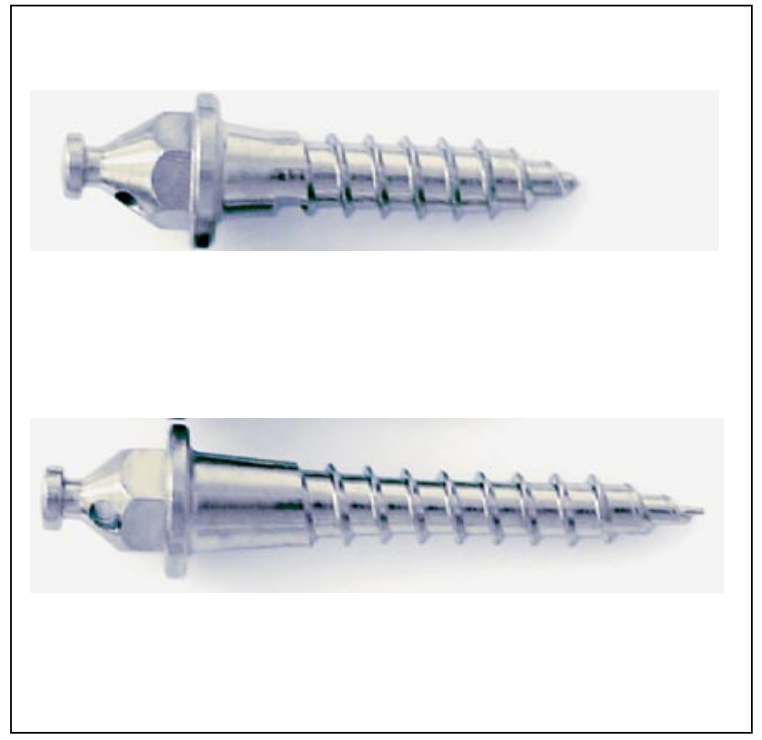

FIGURA 1 - Miniimplantes com diferentes comprimentos da ponta ativa e do perfil transmucoso.

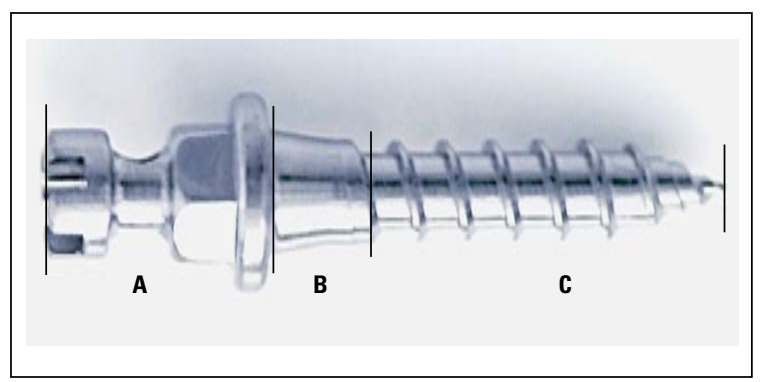

FIGURA 2 - Partes do miniimplante: A) cabeça; B) perfil transmucoso e C) ponta ativa.

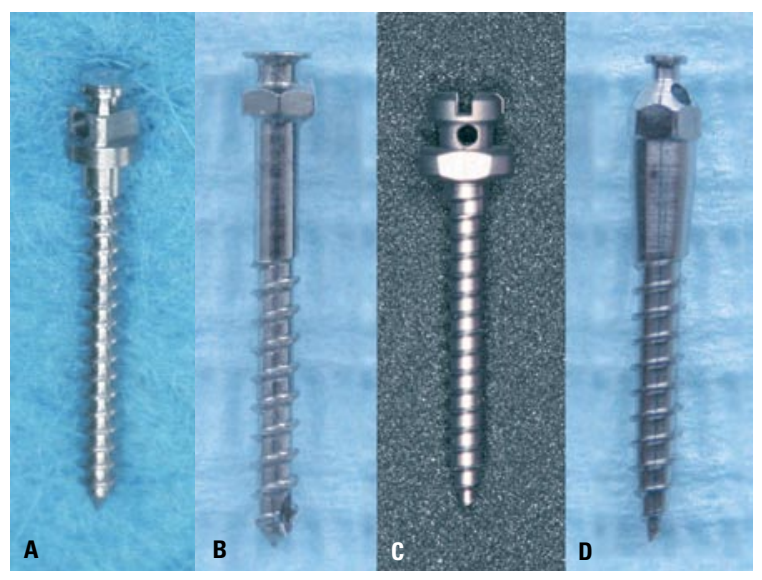

FIGURA 3 - Modelos de diferentes cabeças de miniimplantes, sendo A, B) autorosqueantes e C, D) autoperfurantes. 

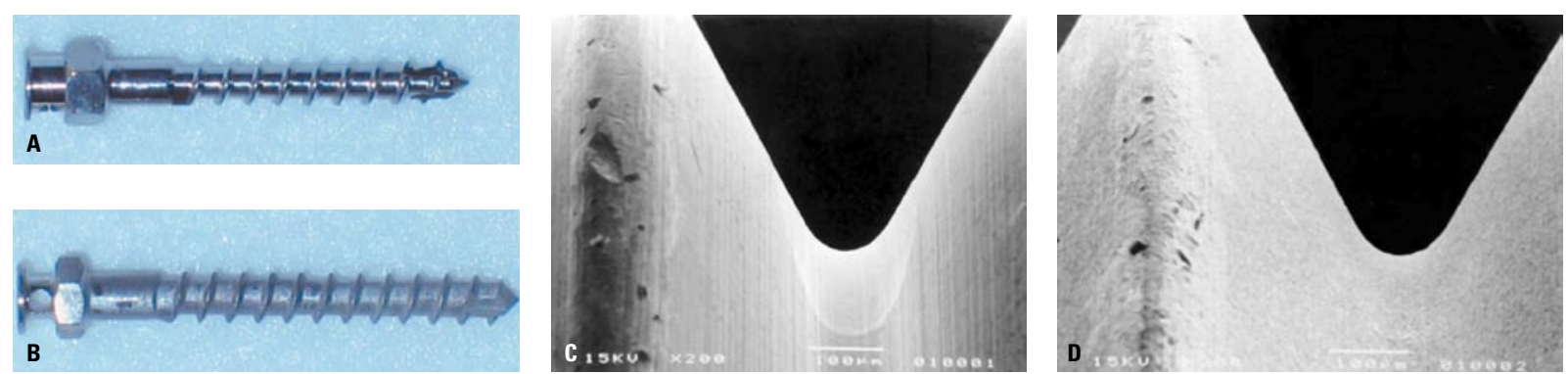

FIGURA 4 - Miniimplantes de titânio: A) grau V; B) grau IV. Imagens em microscópio eletrônico de varredura com aumento de 200x: C) sem tratamento de superfície; D) com tratamento de superfície.

O perfil transmucoso é a área compreendida entre a porção intra-óssea e a cabeça do miniimplante, onde ocorre a acomodação do tecido mole periimplantar ${ }^{36}$. Usualmente constituída em titânio polido, sua altura pode variar de $0,5 \mathrm{a} 4 \mathrm{~mm}$ e deve ser selecionado de acordo com a espessura da mucosa da região onde o miniimplante ortodôntico está sendo instalado ${ }^{28}$. Como exemplo, implantes instalados no palato, usualmente, requerem perfis transmucosos mais longos, entre 2 e $4 \mathrm{~mm}$, ao passo que na face vestibular da mandíbula esta medida é restrita a $0,5 \mathrm{~mm}$. O perfil transmucoso é fundamental para que haja a possibilidade de manutenção da saúde dos tecidos periimplantares, sobretudo em regiões de mucosa ceratinizada, uma vez que a ausência de inflamação, nesta área, é fator relevante para a estabilidade do miniimplante ${ }^{39}$.

A ponta ativa é a porção intra-óssea correspondente às roscas do implante. Certamente, quanto maior quantidade de roscas, maior será a resistência ao deslocamento e a estabilidade primária.

O miniimplante pode ser autorosqueante ou autoperfurante (Fig. 3). O primeiro, devido ao poder de corte presente, após a osteotomia inicial (perfuração da mucosa gengival e cortical óssea com uma fresa), cria seu caminho de entrada no osso. O segundo, por não necessitar de fresagem óssea, tem o processo operatório mais simples e rápido. Acredita-se que os autoperfurantes apresentam maior estabilidade primária e oferecem maior resistência à aplicação de carga ortodôntica imediata $^{27,45}$.
Segundo Favero, Brollo e Bressan ${ }^{19}$, a forma do implante deve promover ancoragem mecânica, através de superfície de contato ósseo, que permita a distribuição da carga funcional sem causar danos à fisiologia do tecido ósseo, sendo os formatos mais usados o cilíndrico e o cônico. Deve ainda limitar ao máximo o trauma cirúrgico no momento da instalação e fornecer boa estabilidade primária.

Atualmente, os principais sistemas para ancoragem esquelética disponíveis nos mercados nacional e internacional utilizam o titânio de grau $\mathrm{V}$ de pureza em sua fabricação (Fig. 4A), cuja principal característica é não viabilizar a formação de interface osseointegrável. Isto é importante porque estes miniimplantes deverão ser removidos após concluída sua função durante o tratamento ortodôntico.

A possibilidade, entretanto, de estabelecimento de uma interface osseointegrada, e conseqüente aumento de estabilidade titânio/osso, devido à união biológica entre estas estruturas, tem boa aplicabilidade clínica em casos selecionados, em regiões que apresentam baixa densidade óssea, como a tuberosidade maxilar. Os miniimplantes osseointegráveis podem ainda ser usados em áreas que já tenham apresentado insucessos com a utilização dos DATs não osseointegráveis, sendo que este tópico tem sido motivo de estudo para pesquisadores e fabricantes do setor.

Algumas empresas, para tanto, têm produzido e comercializado miniimplantes ortodônticos em 
titânio de grau IV, tratados com duplo ataque ácido, de forma a permitir osseointegração (Fig. 4B). Pesquisas laboratoriais e clínicas, a fim de avaliar sua maior efetividade como sistema de ancoragem esquelética, têm sido implementadas. Nestas pesquisas, uma das principais dúvidas está relacionada à possibilidade de sua remoção sem que ocorra fratura do mesmo.

As figuras $4 \mathrm{C}$ e D mostram imagens dos miniimplantes grau V e grau IV de titânio comercialmente puros, obtidos em microscópio eletrônico de varredura, com aumento de 200X. Os de grau $\mathrm{V}$ apresentam superfície usinada e os de grau IV superfície tratada com duplo ataque ácido, proporcionando alterações de microtopografia de superfície.

\section{SELEÇÃO E INSTALAÇÃO}

Visando ao sucesso da utilização dos miniimplantes como recurso de ancoragem, é imperativo um planejamento cuidadoso e individualizado para cada caso. Após a determinação do plano de tratamento para a correção da má oclusão em questão, o ortodontista definirá o tipo de movimento desejado, a quantidade e os locais para a instalação dos DATs ${ }^{60}$.

Uma avaliação clínica preliminar, com palpação digital do vestíbulo, auxiliará na identificação das raízes dos dentes. Em seguida, deve-se fazer um estudo criterioso, analisando radiografias panorâmica e periapicais, para investigar a disponibilidade óssea para a instalação dos miniimplantes.

Através da radiografia panorâmica obtém-se uma visão geral do caso a ser tratado, sendo que uma avaliação cuidadosa, com exame radiográfico periapical, realizado pela técnica do paralelismo, proporciona uma informação mais segura quanto ao espaço disponível, de forma a orientar na definição do local e diâmetro ideal do implante. Esta atenção evita ou minimiza a possibilidade de lesão às estruturas anatômicas, durante a instalação $0^{33,41}$.

A seleção do diâmetro e comprimento dos mi-

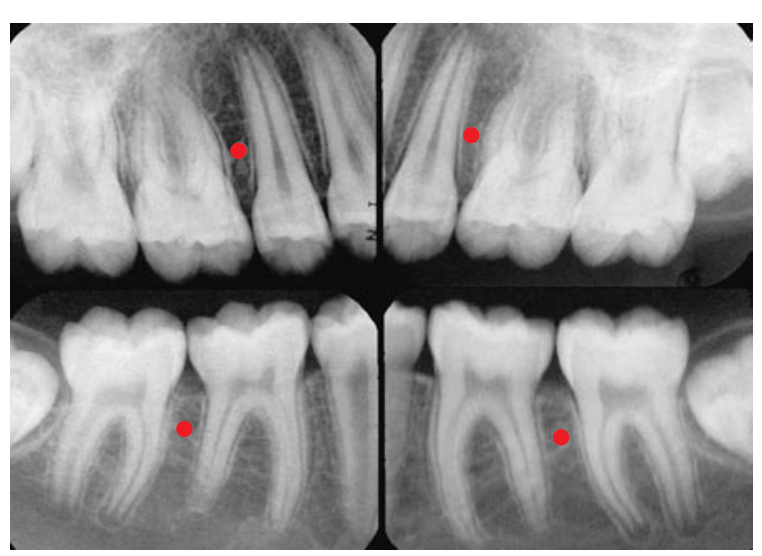

FIGURA 5 - Radiografias periapicais com orientação para a instalação de miniimplantes entre segundos pré-molares e primeiros molares na arco superior, e entre primeiros e segundos molares na arco inferior.

niimplantes é fator importante no processo de utilização destes. Apesar de poderem ser instalados nos mais diversos sítios, tanto da maxila quanto da mandíbula, em áreas onde o espaço é extremamente reduzido, é necessária apurada habilidade manual e a eleição de implantes de diâmetro e tamanho adequados à área em questão.

Os dispositivos temporários para ancoragem esquelética podem ser instalados pelo ortodontista ou implantodontista. Quando forem instalados pelo implantodontista, este deverá receber orientação precisa para que não existam dúvidas quanto à posição eleita. Esta comunicação deverá ser por correspondência, com redação clara, contendo informações detalhadas, por imagens digitais de radiografias apontando o local da instalação (Fig. 5), sinalização em modelos de gesso (Fig. 6) ou ainda através do fornecimento de guias, sejam em aço, latão ou acrílico (Fig. 7). Em contrapartida, o implantodontista, diante da impossibilidade de instalação no local solicitado, poderá sugerir sítios alternativos.

Poggio et al..$^{50}$, em trabalho utilizando tomografias, observou que na região posterior, tanto da maxila quanto da mandíbula, a maioria dos espaços interradiculares possui área suficiente para a instalação de miniimplantes. Na maxila, a maior disponibilidade óssea se localiza entre o primeiro 

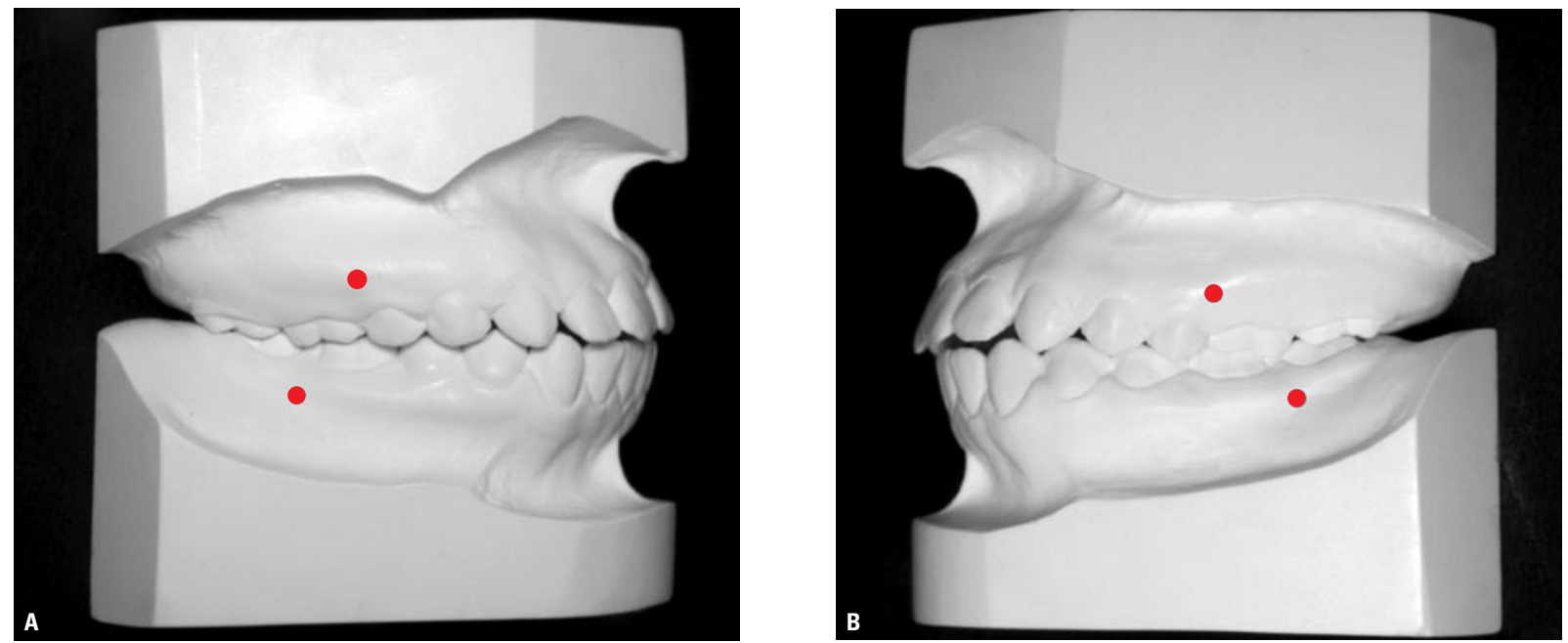

FIGURA 6 - Marcação em modelos de gesso indicando a localização dos miniimplantes, lados direito (A) e esquerdo (B).
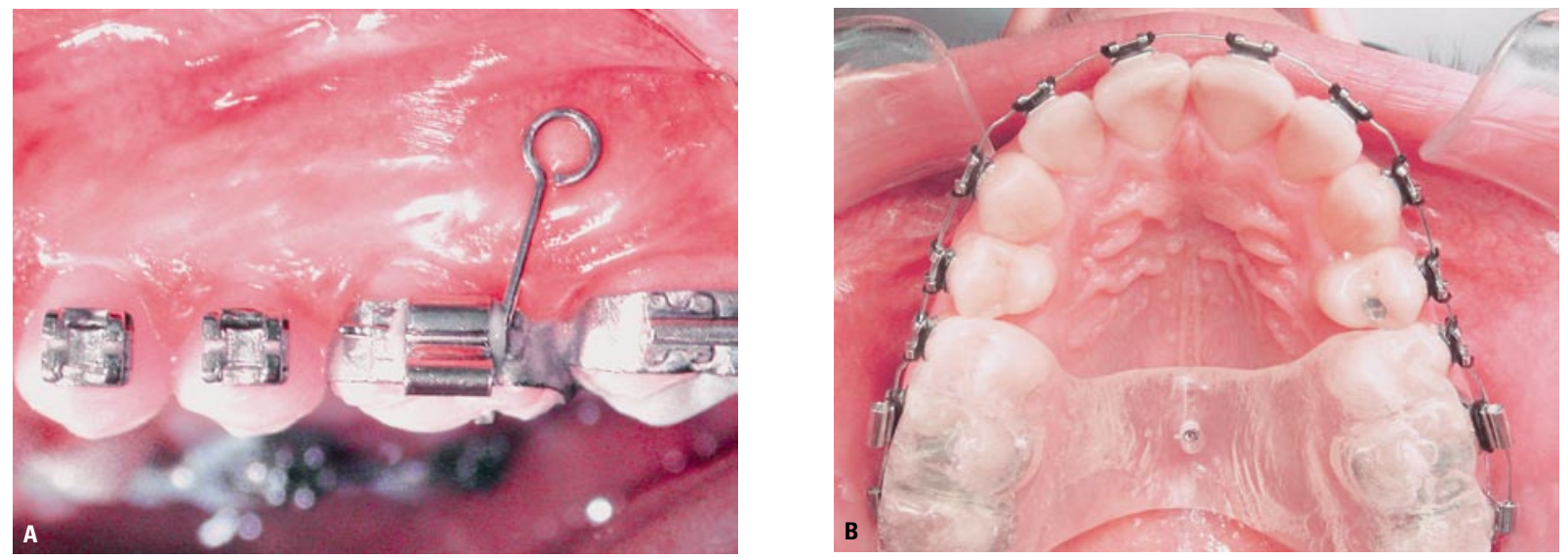

FIGURA 7 - Tipos de guias utilizadas para a instalação de miniimplantes: A) fio de aço inoxidável entre as raízes dos molares; B) acrílico, no palato.

e o segundo pré-molar, seguidas das áreas entre primeiro pré-molar e canino, e segundo pré-molar e primeiro molar, sendo maior por palatina que por vestibular. $\mathrm{Na}$ mandíbula, as maiores áreas interdentárias disponíveis para a inserção de miniimplantes são entre primeiros e segundos molares, seguidas pelos espaços entre primeiros e segundos pré-molares, segundos pré-molares e primeiros molares, e primeiros pré-molares e caninos, gradativamente. Observou-se, ainda, aumento de cervical para apical, devido à forma cônica das raízes. Destarte, quanto menor o espaço disponível, menor deverá ser o diâmetro do implante.

Para critério de seleção, o espaço disponível en- tre as raízes, no sentido mesiodistal, na área cirúrgica eleita, deverá ser, no mínimo, o correspondente ao diâmetro do implante somado a 1,5 mm. Isso se deve ao fato de o espaço periodontal radicular possuir, em média, $0,25 \mathrm{~mm}$ para cada raiz e ser necessário mais $1 \mathrm{~mm}$ de margem de segurança ${ }^{51}$. Portanto, no caso de eleição de um miniimplante ortodôntico de $1,4 \mathrm{~mm}$ de diâmetro, a distância entre as raízes deverá ser de, no mínimo, 2,9mm. Caso esta distância não esteja disponível, há necessidade de se avaliar a possibilidade de utilização de posicionamentos anatômicos alternativos, modificar a angulação de instalação do miniimplante ortodôntico ou, ainda, promover, ortodonticamente, 

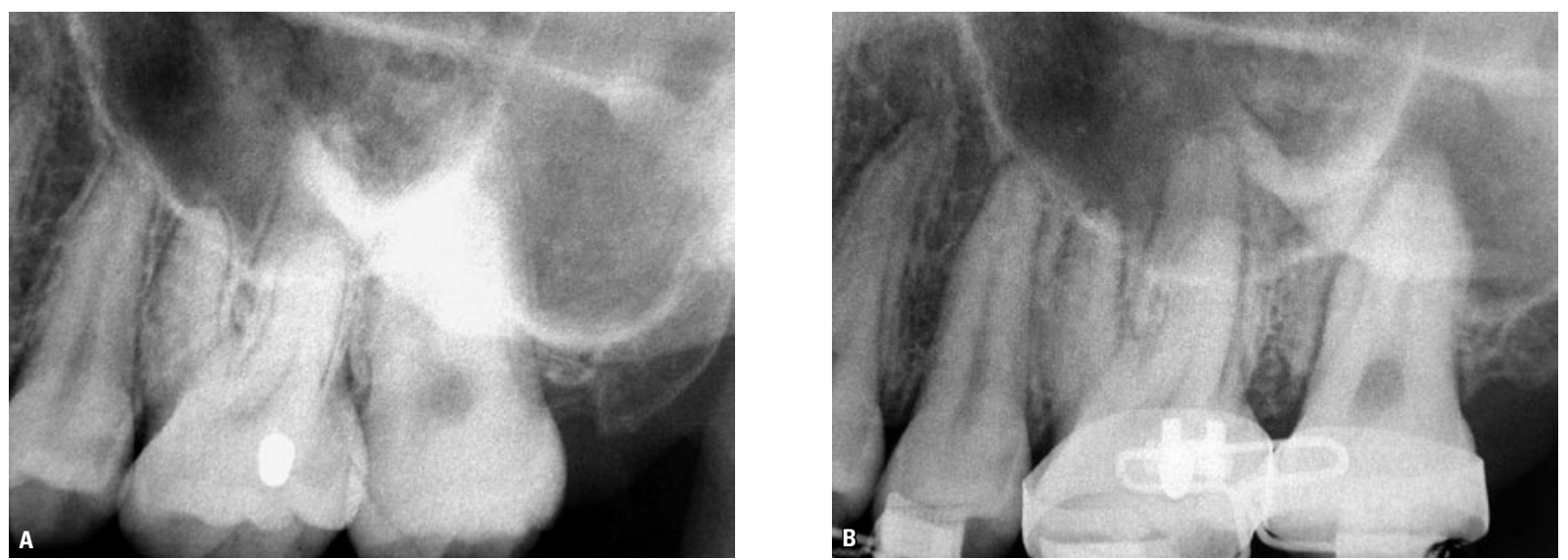

FIGURA 8 - Radiografias periapicais da região posterior superior: A) sem espaço para a instalação dos miniimplantes entre os molares; $\mathbf{B}$ ) presença de espaço, obtido ortodonticamente, entre os molares.

o afastamento das raízes, de forma a aumentar o espaço para que a fixação do miniimplante seja realizada com segurança (Fig. 8).

Segundo Schnelle et al..$^{53}$, que analisaram radiografias panorâmicas pré-tratamento ortodôntico, poucos espaços interdentários teriam dimensões suficientes para acomodar miniimplantes, com exceção das regiões mais apicais, as quais provavelmente estariam em área de mucosa livre. Nas radiografias pós-tratamento, porém, houve aumento considerável destes espaços. Este fato sugere a necessidade de um alinhamento inicial, em alguns casos, antes da instalação de miniimplantes.

Os miniimplantes podem ser usados nos diversos diâmetros, desde que o local de eleição apresente espaço suficiente. Normalmente, porém, são utilizados os dispositivos de $1,2 \mathrm{~mm}$ para a instalação entre raízes, em áreas de alta densidade óssea (palato e mandíbula) e quando obtém-se boa estabilidade primária; os de $1,4 \mathrm{~mm}$ entre raízes dentárias que apresentem maior espaço, áreas com densidade óssea média (maxila) ou caso o de $1,2 \mathrm{~mm}$ não obtenha boa estabilidade primária. Os de 1,6mm são mais usados em regiões edêntulas, áreas de baixa densidade óssea (tuberosidade) ou caso o de $1,4 \mathrm{~mm}$ não apresente estabilidade inicial adequada ${ }^{41}$.

A estabilidade primária é de vital importância para a obtenção de um sistema de ancoragem confiável. Este dado, no entanto, apresenta alto grau de subjetividade, já que não existem trabalhos científicos mensurando o nível de estabilidade destes dispositivos, assim como definindo qual seria o melhor grau de estabilização inicial.

$\mathrm{Na}$ prática clínica, a estabilidade primária do implante poderá ser aferida durante o seu assentamento, através da avaliação da necessidade de se aplicar maior ou menor força à chave digital, uma vez que, quanto maior a resistência ao assentamento, maior a estabilidade inicial do dispositivo. Clinicamente, também após a fixação do mesmo, pode-se pressionar a cabeça do implante com instrumento metálico em diferentes sentidos e, em casos de baixa estabilidade, haverá isquemia na região periimplantar, denotando necessidade de substituição do aparato por um de maior diâmetro ou eleição de outro sítio de instalação (Fig. 9). Este teste clínico deverá ser realizado não só após a cirurgia, mas sempre que o sistema for ativado. Isto porque um miniimplante pode ter excelente estabilidade primária e, no decorrer do tratamento, apresentar mobilidade.

Para incrementar os índices de sucesso, a realização de uma técnica cirúrgica precisa e a utilização de alguns parâmetros são fundamentais. Para instalação dos miniimplantes autorosqueantes, 

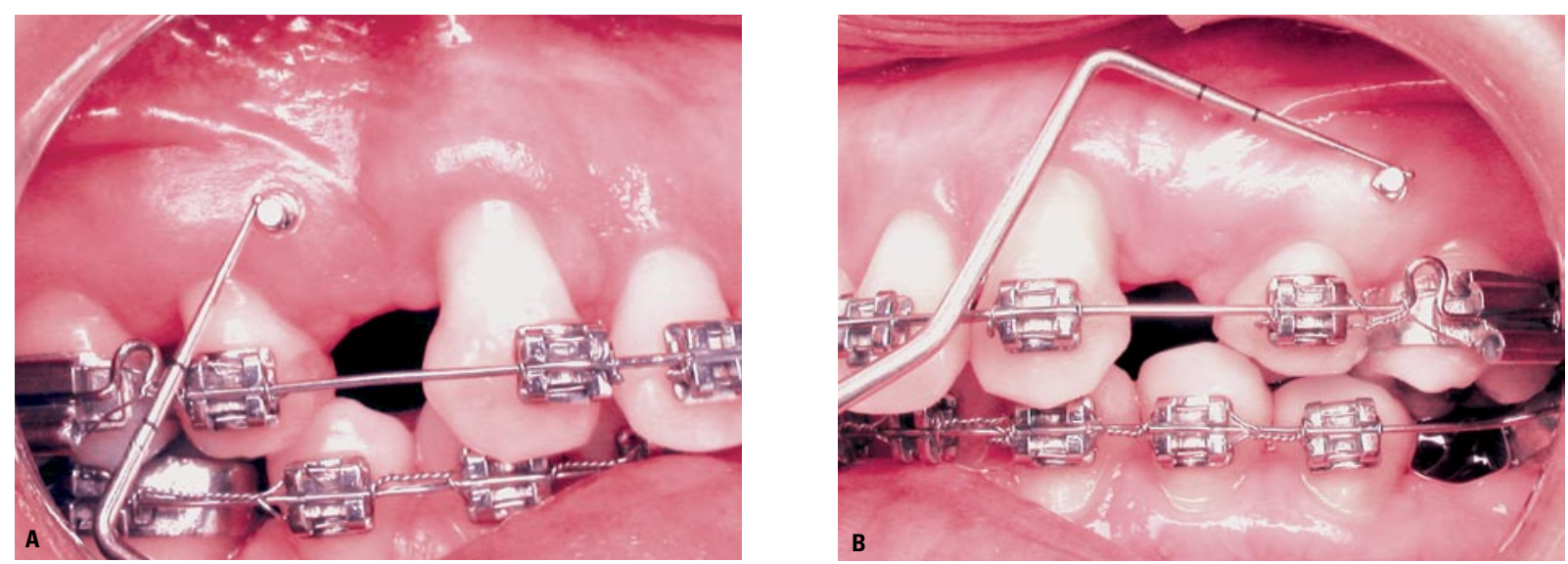

FIGURA 9 - Avaliação clínica da mobilidade dos miniimplantes: A) sem mobilidade e B) com mobilidade, evidenciada pela isquemia do tecido periimplantar.

usualmente, o diâmetro do implante deve ser em média 0,2 a $0,3 \mathrm{~mm}$ superior ao diâmetro da fresa utilizada para a osteotomia. Esta combinação proporciona bom nível de estabilidade inicial, sem gerar excesso de compressão da interface óssea, que poderia levar à isquemia nesta área, conseqüente fibrose por hialinização e perda de estabilidade do miniimplante ortodôntico.

A sensibilidade clínica durante a osteotomia em relação à densidade óssea da região operada também colabora para a seleção adequada do diâmetro do miniimplante. Áreas que apresentem baixa densidade podem exigir um dispositivo com diâmetro 0,4 ou $0,6 \mathrm{~mm}$ superior ao da fresa para que um bom nível de estabilidade primária possa ser alcançado.

No que diz respeito à seleção do comprimento ideal do miniimplante ortodôntico a ser utilizado, deverão ser levadas em consideração a estabilidade primária e a preservação das estruturas nobres vizinhas à área operada, como raízes e feixes vásculo-nervosos ${ }^{43}$. Como regra geral, quanto mais longo o miniimplante, melhor a área de contato osso/implante e, conseqüentemente, maior a estabilidade ${ }^{7}$.

Os miniimplantes mais utilizados são os de comprimento variando de 6 a $10 \mathrm{~mm}$, tanto para a mandíbula quanto para a maxila, apesar destas estruturas apresentarem densidades ósseas diferentes ${ }^{4,60}$.

Para a instalação de miniimplantes no palato é necessária adequada avaliação da espessura da mucosa, que pode ser mensurada através da utilização de um cursor de borracha transpassado pela agulha da anestesia, permitindo uma aferição satisfatória com o auxílio de uma régua ou sonda milimetra$\mathrm{da}^{28}$. Como cerca de $6 \mathrm{~mm}$ do miniimplante devem penetrar no osso, conhecendo-se a espessura da mucosa palatal é possivel definir o tamanho do perfil transmucoso e do miniimplante (Fig. 10).

Portanto, a seleção do diâmetro e comprimento ideais dependerá da avaliação individualizada do caso a ser tratado, norteando-se pela disponibilidade óssea presente, densidade óssea no local da instalação, estabilidade primária alcançada, demanda ortodôntica presente e preservação da integridade das estruturas anatômicas.

Após o planejamento com definição do tamanho do parafuso e eleição do local de instalação, uma consulta deve ser programada para avaliação das condições periodontais e de higiene bucal do paciente. Caso estes ítens não estejam a contento, orientação e controle devem ser realizados até que o paciente apresente nível adequado de saúde bucal $^{41}$.

Embora alguns autores ${ }^{6,36}$ não preconizem 


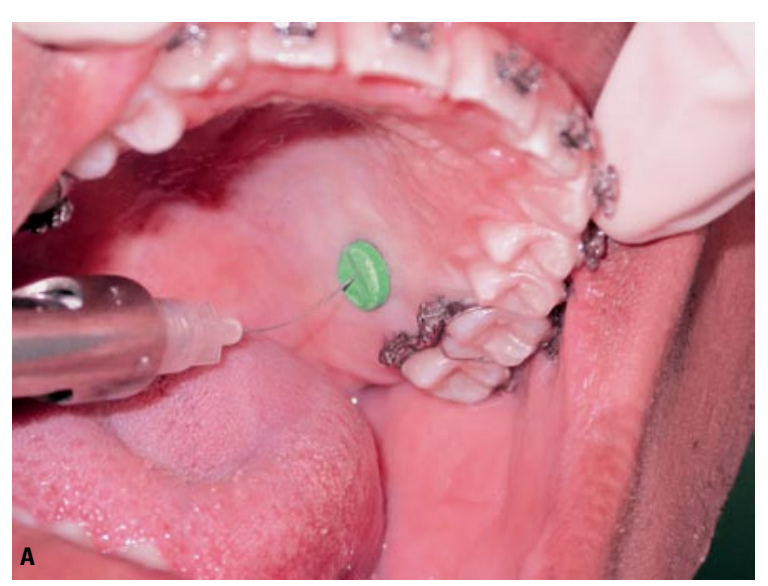

FIGURA 10 - Aferição da espessura da mucosa palatina: A) agulha anestésica com cursor de borracha e B) avaliação da espessura da mucosa com a sonda milimetrada.

profilaxia medicamentosa especifica para minimizar o risco de infecção ou inflamação dos tecidos periimplantares, temos sugerido a utilização de cobertura antibiótica pré-cirúrgica, seguindo o protocolo de profilaxia da endocardite bacteriana (ex: $2 \mathrm{~g}$ de amoxicilina uma hora antes do procedimento operatório). Recomendamos, também, a utilização de medicação antiinflamatória (ex: etoricoxib $120 \mathrm{mg}$ durante três dias) que, juntamente com o antibiótico, tem o intuito de eliminar variáveis que poderiam influenciar nos indices de sucesso deste tipo de terapia ${ }^{41}$. Apesar da ausência de estudos longitudinais controlados, testando a relevância da prescrição medicamentosa, acreditamos que, sobretudo por se tratar de uma técnica nova, onde muitas variáveis ainda se encontram presentes (como índices reais de sucesso em diferentes situações clínicas, tempo e força ideal para ativação ortodôntica, desenho mais adequado e critérios de higienização, entre outras), a eliminação de fatores como o risco de infecção/ inflamação faz-se necessária para o estabelecimento de um protocolo rígido que possa ser aplicado às diferentes situações clínicas e aumente os níveis de previsibilidade de resultados.

A cirurgia de instalação dos miniimplantes ortodônticos, apesar de extremamente simples e rápida, deverá seguir um protocolo cirúrgico cui-

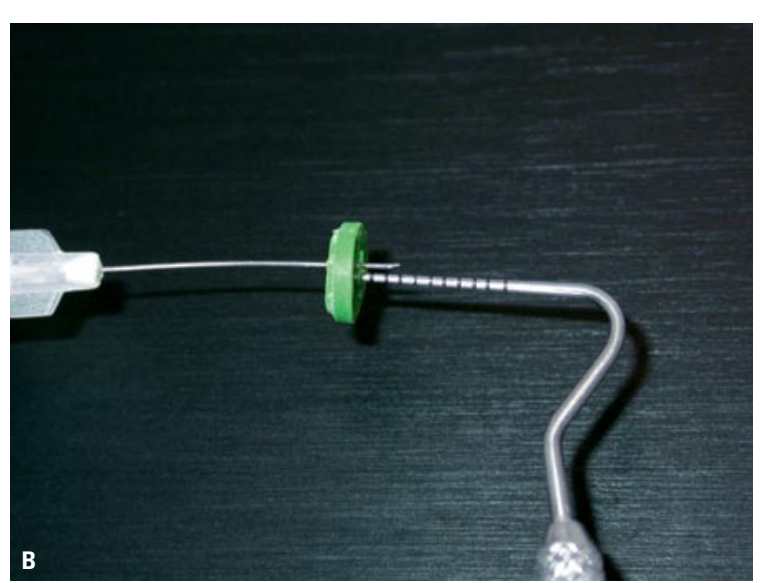

dadoso. Para orientação do ortodontista ou implantodontista, um guia cirúrgico pode ser confeccionado com fio de latão $(0,6 \mathrm{~mm}$ de espessura) passando através do ponto de contato entre as unidades dentárias, com extensão na direção apical. A imagem radiopaca do guia, visualizada na radiografia periapical, representa uma referência para o correto posicionamento do miniimplante (Fig. 11A, B), minimizando riscos de lesões às estruturas anatômicas ${ }^{30,41,44}$.

Vale ressaltar que este ou outros tipos de guias ilustrados na literatura são úteis para orientar a instalação dos miniimplantes $s^{6,36,40,41,57,60}$, sendo necessária, no entanto, avaliação radiográfica criteriosa do marcador radiopaco, uma vez que pequenas distorções verticais ou horizontais, no momento da tomada da radiografia, poderão gerar imagens falsas no posicionamento do guia. Os dados radiográficos obtidos com o guia radiopaco em posição deverão ser associados à experiência profissional e sensibilidade tátil, durante o momento da instalação dos DATs. Um profissional com experiência, porém, na maioria dos casos, não utiliza o guia com fio de latão ou outros tipos citados na literatura, orientando-se apenas pela investigação clínica e radiográfica.

A intervenção pode ser realizada em ambiente ambulatorial, sob anestesia local infiltrativa subpe- 

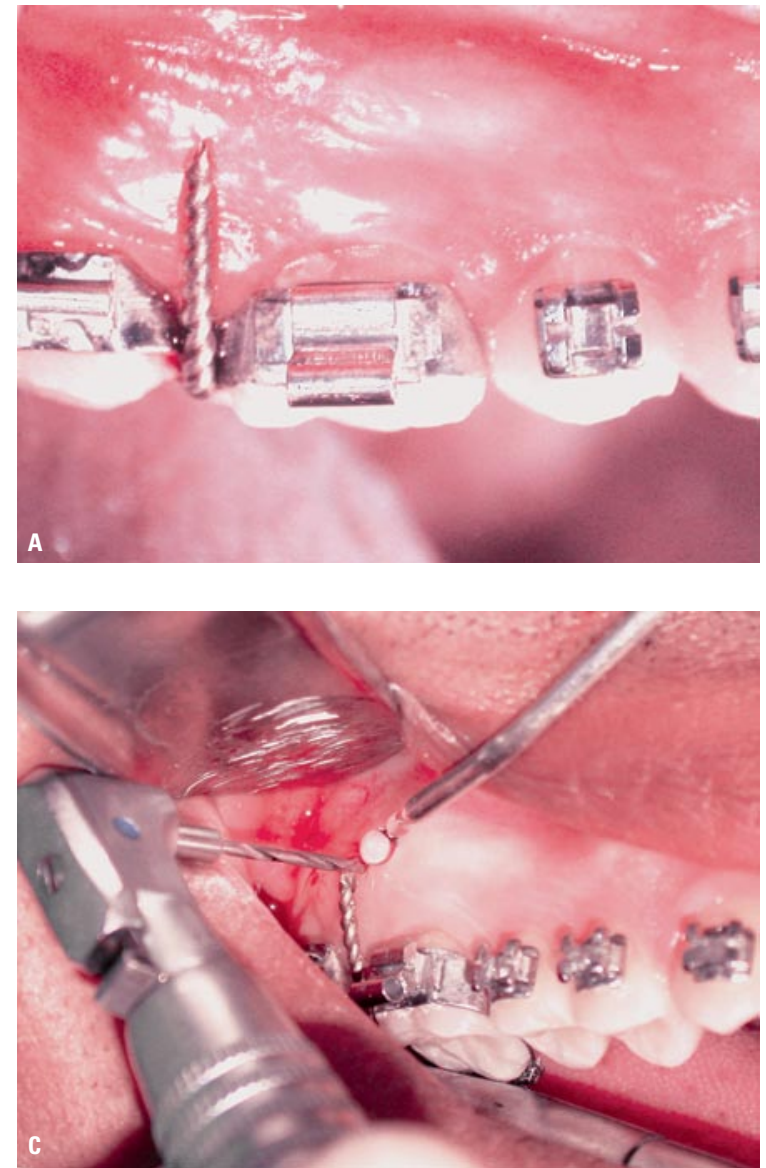
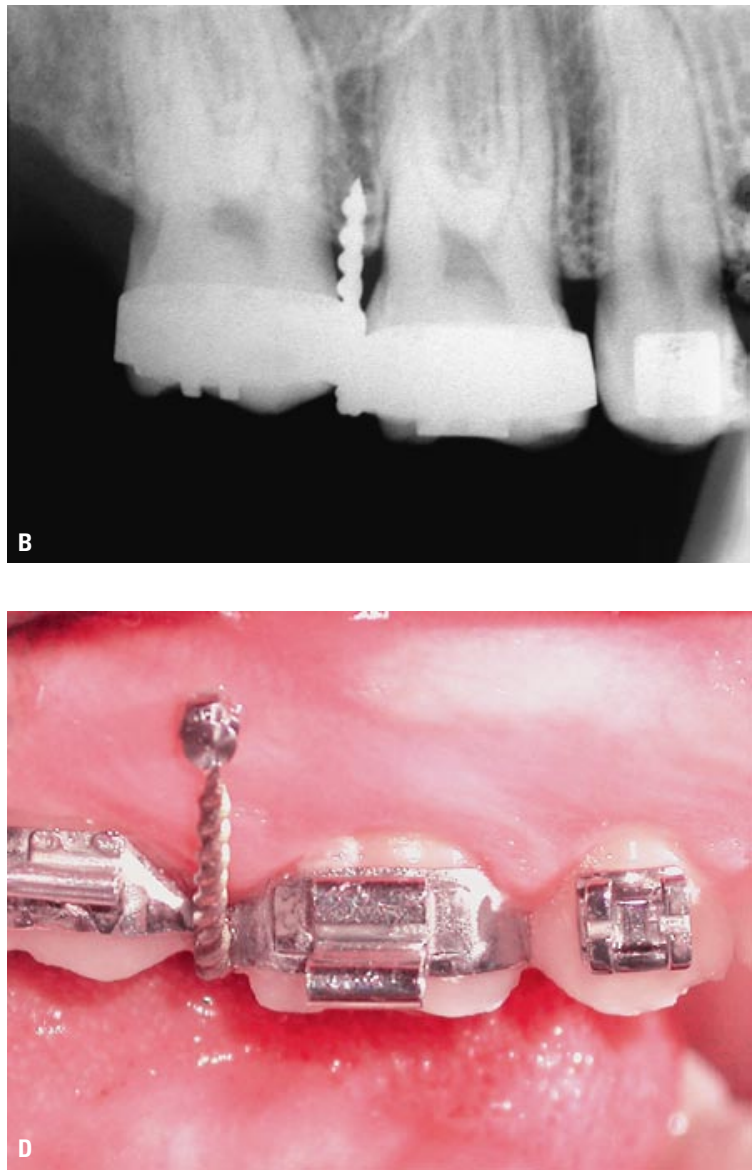

FIGURA 11 - Seqüência de instalação do miniimplante: A) cursor de latão posicionado; B) radiografia periapical visualizando o cursor entre as raízes dos molares; C) perfuração da mucosa e cortical óssea com motor cirúrgico e fresa helicoidal; D) miniimplante imediatamente após a instalação.

riosteal, ou com a utilização de anestésico tópico periodontal de efeito profundo. Para favorecer a percepção de um possível contato indesejado com raízes, não é recomendável ação anestésica sobre as unidades dentárias vizinhas ${ }^{36}$. A loja óssea para inserção dos miniimplantes poderá ser preparada de forma transmucosa, com motor de baixa rotação (máxima de 300rpm), utilizando broca helicoidal sob irrigação profusa com solução salina, evitandose assim o aquecimento ósseo ${ }^{4}$ (Fig. 11C, D).

Em muitos casos, não é necessário o aprofundamento da osteotomia, perfurando-se apenas a cortical alveolar, e ficando por conta do rosqueamento do parafuso a criação do restante do leito ${ }^{6}$. O miniimplante deve apresentar bom travamento no sítio de inserção. Havendo mobilidade, este deve ser removido e substituído por um de diâmetro imediatamente maior, levando-se em consideração o espaço existente.

Para auxiliar na estabilidade e facilitar a higienização, deve-se ainda inserir o miniimplante em área de mucosa ceratinizada, evitando as regiões de mucosa não-ceratinizada mais próximas ao fundo de vestíbulo ${ }^{36}$.

Com o objetivo de alcançar maior estabilidade primária e evitar proximidade com as raízes, recomenda-se, na maxila, a instalação de miniimplantes com inclinação perpendicular ou com angulação de até 30 a 40 graus em relação ao longo eixo dos dentes $7,28,50$. Esta inclinação proporciona maior área de contato do implante com o osso, além de reduzir o risco de atingir raízes dentá- 

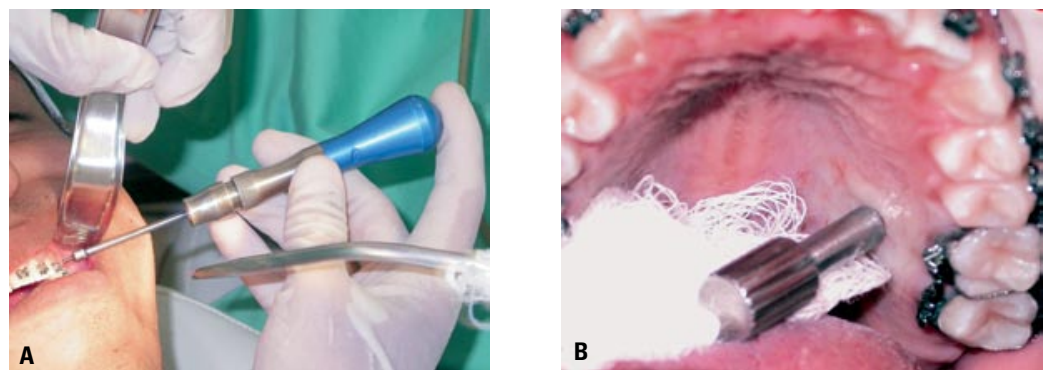

FIGURA 12 - Instalação do miniimplante: A) chave manual longa; B) chave manual curta e C) motor cirúrgico.

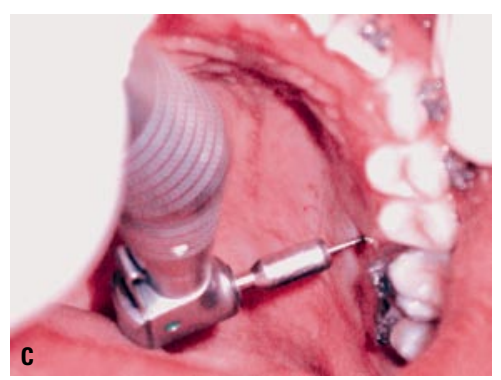

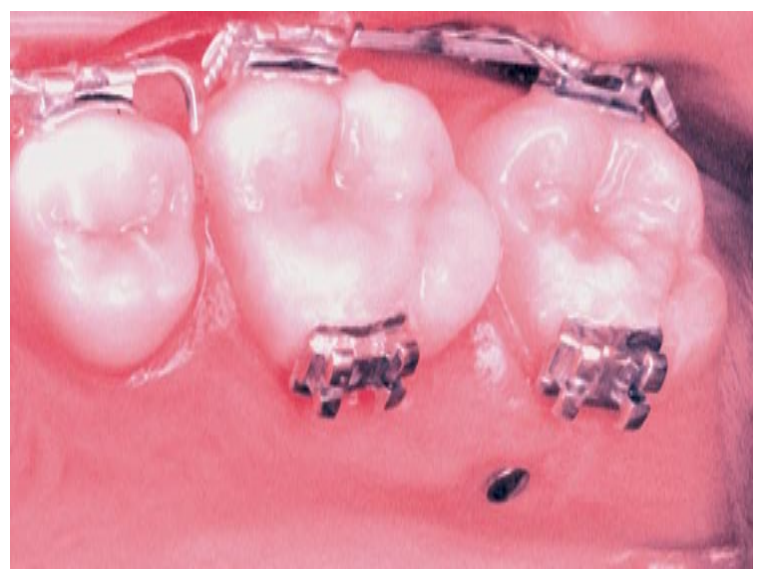

FIGURA 13 - Miniimplante com a cabeça quase submersa na mucosa palatina.

rias. Quando os miniimplantes são planejados para intrusão de dentes póstero-superiores, e necessitem estar posicionados mais altos, estes devem ser instalados perpendicularmente ao osso para evitar uma perfuração do seio maxilar ${ }^{6,50}$. $\mathrm{Na}$ mandíbula, devido à maior espessura da cortical óssea, pode-se utilizar angulação de perpendicular até 10 a 20 graus em relação ao longo eixo dos dentes. A densidade do osso cortical varia de paciente para paciente, podendo, ainda, num mesmo indivíduo, apresentar diferenças entre os lados direito e esquerdo ${ }^{28}$.

Os dispositivos transitórios de ancoragem do tipo miniimplante podem ser inseridos no osso alveolar através de chaves manuais curtas ou longas, ou ainda chaves mecânicas acopladas ao motor cirúrgico em baixa rotação (20rpm) sob irrigação profusa com solução salina para evitar aquecimento ósseo (Fig. 12). Como cuidado operatório é válido alertar que, quando da utilização da chave curta no palato, devido às suas dimensões reduzidas, deve-se ter a atenção de utilizar uma gaze de forma a impedir um possivel acidente, como a deglutição do instrumento (Fig. 12B). Preferencialmente, a instalação dos parafusos autorosqueantes ou autoperfurantes deverá ser realizada com a chave manual longa, uma vez que a mesma facilita a instalação dos miniimplantes e transfere para o operador a sensibilidade tátil em relação à densidade óssea e resistência à inserção, fundamentais para o perfeito diagnóstico da estabilidade primária, assim como para minimizar o risco de lesão às raízes dentárias vizinhas. Em contrapartida, apesar de menos eficiente quanto à sensibilidade tátil no momento da instalação dos miniimplantes, a utilização da chave mecânica viabiliza a inserção dos DATs em locais com difícil acesso para as chaves manuais, como por exemplo o palato, a tuberosidade maxilar e a região retromolar.

Atenção deve ser dada ao rosqueamento do implante para que a cabeça deste não fique submersa na mucosa, dificultando a instalação de elásticos, molas ou amarrilhos (Fig. 13). O orifício presente na cabeça deve, preferencialmente, estar com seu eixo no sentido ântero-posterior, de forma a facilitar a penetração de amarrilhos. Quando a luz do orifício se encontra no sentido vertical, dependendo da inclinação vertical do implante, pode-se ter dificuldade na inserção do amarrilho metálico (Fig. 14).

Quanto ao tempo cirúrgico, considerando-se a preparação do paciente, inserção do miniimplante 

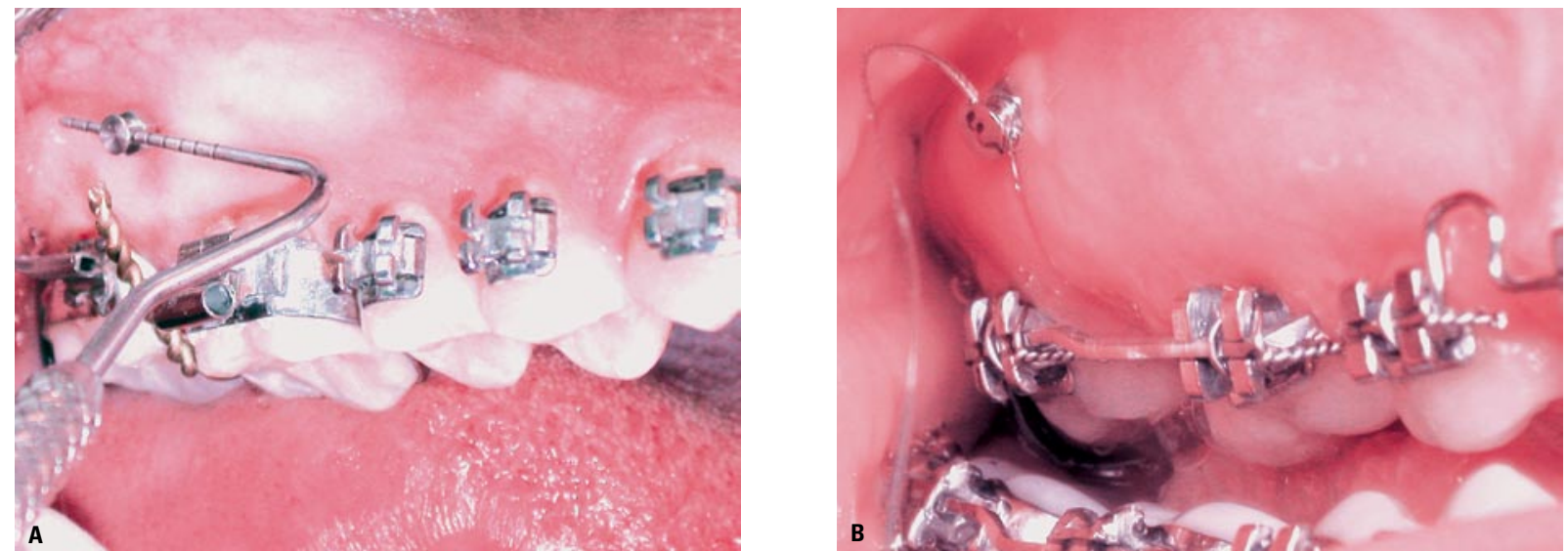

FIGURA 14 - Direção do orifício da cabeça do miniimplante: A) no sentido horizontal, de modo a facilitar a inserção de amarrilho metálico; B) no sentido vertical, dificultando a passagem do amarrilho, devido à inclinação apresentada.

e orientação sobre procedimentos de manutenção de saúde periimplantar, o tempo de atendimento não é maior que 30 minutos.

É importante a realização de radiografia periapical final da região com o objetivo de verificar se a colocação do miniimplante foi realizada corretamente ${ }^{28}$.

De acordo com Kyung et al. ${ }^{28}$, o sucesso do tratamento com miniimplantes depende dos seguintes fatores: a) habilidade do cirurgião; b) condição física do paciente; c) seleção do local adequado; d) estabilidade inicial e e) higiene bucal.

\section{HIGIENE PERIIMPLANTAR}

A orientação de higiene pós-cirúrgica é importante para evitar inflamação periimplantar, o que pode comprometer a estabilidade futura do miniimplante ${ }^{36,39}$. Nas primeiras duas semanas, recomenda-se que o paciente higienize o local de inserção do implante com escova periodontal extra-macia embebida em solução ou gel de gluconato de clorexidina $0,12 \%$ por 30 segundos, 2 vezes ao dia. A indicação desta escova pós-cirúrgica é importante, pois possui cerdas extremamente macias, dando ao paciente a segurança de higienizar uma área que acabou de ser manipulada cirurgicamente (Fig. 15). A partir da terceira semana, a higieniza-

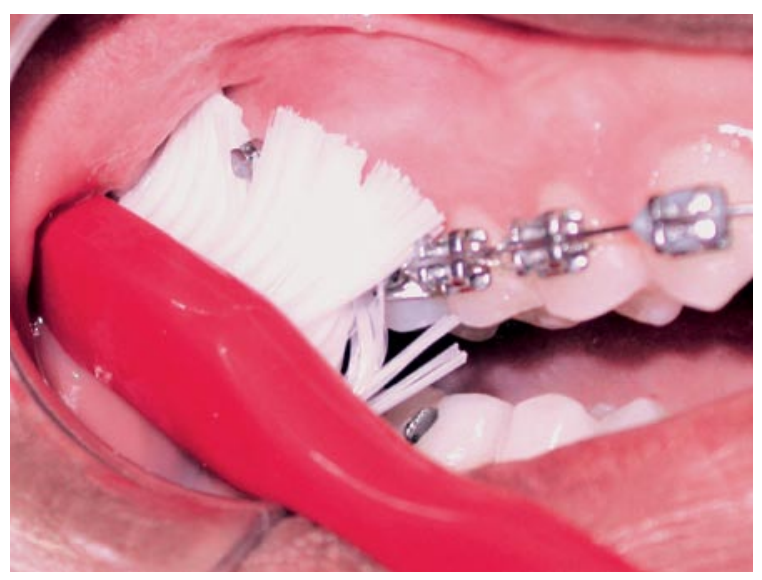

FIGURA 15 - Higiene periimplantar com escova periodontal extra-macia.

ção da área do miniimplante e demais regiões deve ser realizada com escova macia e creme dental. Em adição, deve ser recomendado bochecho com colutório anti-séptico à base de triclosan $0,03 \%$ por 30 segundos, 3 vezes ao dia, durante todo o período do tratamento, tendo em vista seus comprovados efeitos anti-séptico e antiinflamatório ${ }^{41}$.

Um controle profissional da saúde periimplantar deverá ser feito semanalmente no primeiro mês e mensalmente durante todo o tratamento, reforçando a orientação das medidas de controle de biofilme dento-bacteriano ${ }^{41}$. 

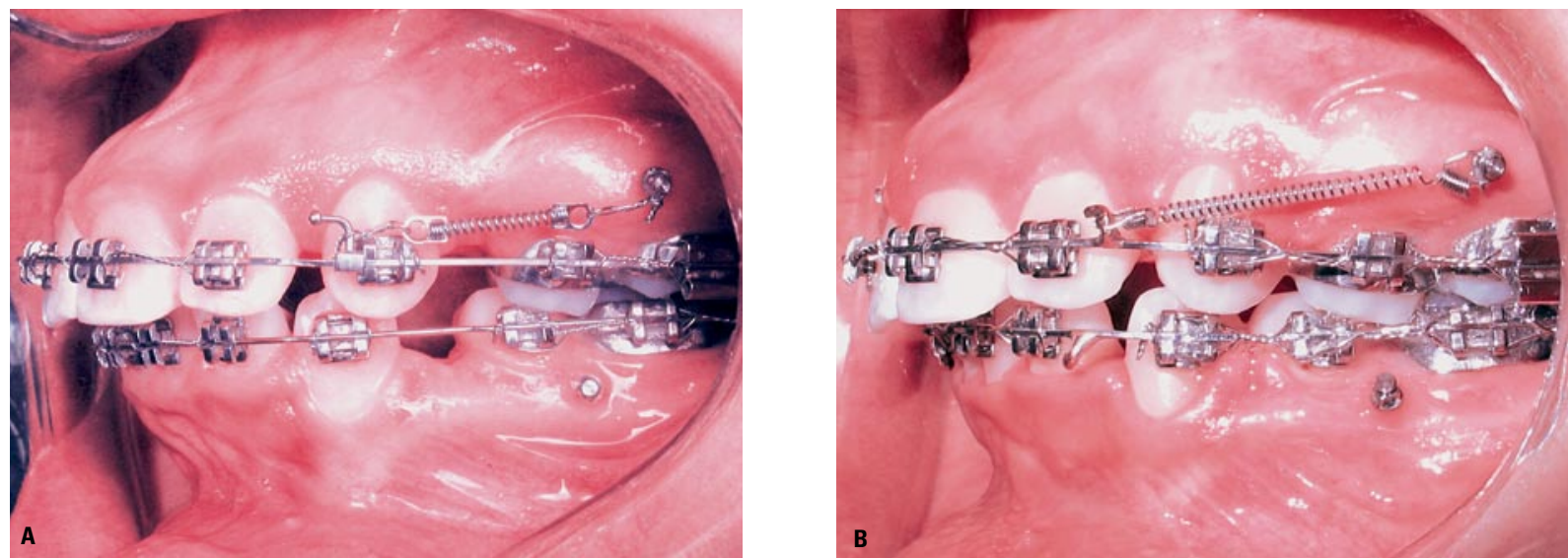

FIGURA 16 - Utilização de miniimplantes para retração de dentes anteriores em duas fases: A) retração dos caninos; B) retração dos incisivos.

\section{APLICAÇÕES CLÍNICAS}

O tamanho reduzido do miniimplante ortodôntico diminui consideravelmente as limitações quanto aos locais de sua possivel inserção. Esta grande variabilidade no que diz respeito às possibilidades de localização para os miniimplantes permite sua utilização, como recurso de ancoragem, nos mais variados tipos de movimentação dentária.

\section{Retração de dentes anteriores}

A retração de dentes anteriores em casos que não permitam perda de ancoragem é talvez a indicação mais citada na literatura para o uso dos miniimplantes ortodônticos 6,10,23,37,42,46. Biprotrusões severas ou Classes II de Angle completas a serem tratadas com extração de pré-molares, diastemas anteriores generalizados a serem fechados por retração dos incisivos e caninos, ou ainda quando se deseja retrair e não há unidades de ancoragem suficientes, são situações nas quais a utilização de miniimplantes, em posições estratégicas, possibilitaria ou simplificaria muito o tratamento.

De acordo com Park ${ }^{43}$, na maxila, o local de eleição para a inserção dos miniimplantes, destinados à retração das unidades anteriores, é entre o segundo pré-molar e o primeiro molar por vestibular, enquanto na mandíbula é entre o primeiro e segundo molar também por vestibular ${ }^{43}$. Estas localizações, além de apresentarem normalmente uma boa distância entre as raízes, permitem que a retração seja realizada sem o risco de contato das unidades que estão sendo movimentadas com o miniimplante. Estas são ainda áreas de fácil acesso para fixação de acessórios. Caso a opção, por algum motivo, seja a extração do segundo prémolar, pode-se manter a posição do miniimplante na maxila, tomando o cuidado de instalá-lo bem próximo do molar, de modo a permitir uma movimentação máxima. Outra opção seria instalá-lo entre o primeiro e segundo molares, sendo que esta área, em muitos casos, não apresenta espaço suficiente entre as raízes. Um estudo radiográfico periapical prévio é imprescindível para avaliação individual da área eleita ${ }^{50}$.

Quanto à altura, pode-se ainda instalar os miniimplantes numa posição mais alta ou mais baixa, favorecendo um controle da sobremordida através da variação da direção da linha de força. Instalase o miniimplante mais apicalmente em pacientes com sobremordida exagerada, nos quais se deseja uma intrusão dos incisivos durante a retração, ou mais próximo das coroas dentárias em pacientes com um bom nível de sobremordida ${ }^{6}$.

A retração dos dentes anteriores pode ser planejada de duas formas, inicialmente com a retração dos caninos, seguida de retração dos quatro incisivos (Fig. 16), ou com retração em massa dos dentes anteriores (Fig. 17). Miniimplantes resis- 
tem bem à retração dos seis dentes anteriores, tendo como grande vantagem a diminuição do tempo de tratamento (Fig. 18).

\section{Mesialização de dentes posteriores}

A mesialização de dentes posteriores, quando não se quer retração dos dentes anteriores, representa um problema para o ortodontista. Seja para fechar espaços de perdas dentárias, compensar casos de Classe II ou III de Angle ou descompensar casos cirúrgicos, a utilização de miniimplantes ortodônticos pode ser de grande valia na simplifica-

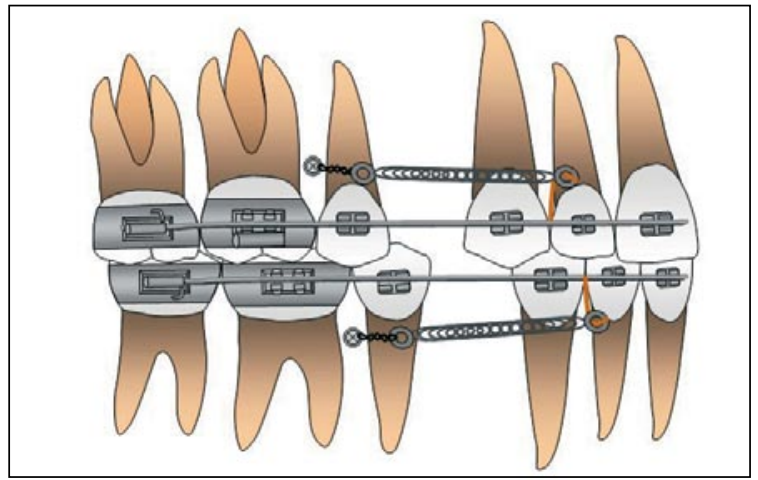

FIGURA 17 - Ilustração de retração em massa dos dentes anteriores, com linha de ação de força horizontal próxima ao centro de resistência do conjunto que está sendo movimentado.
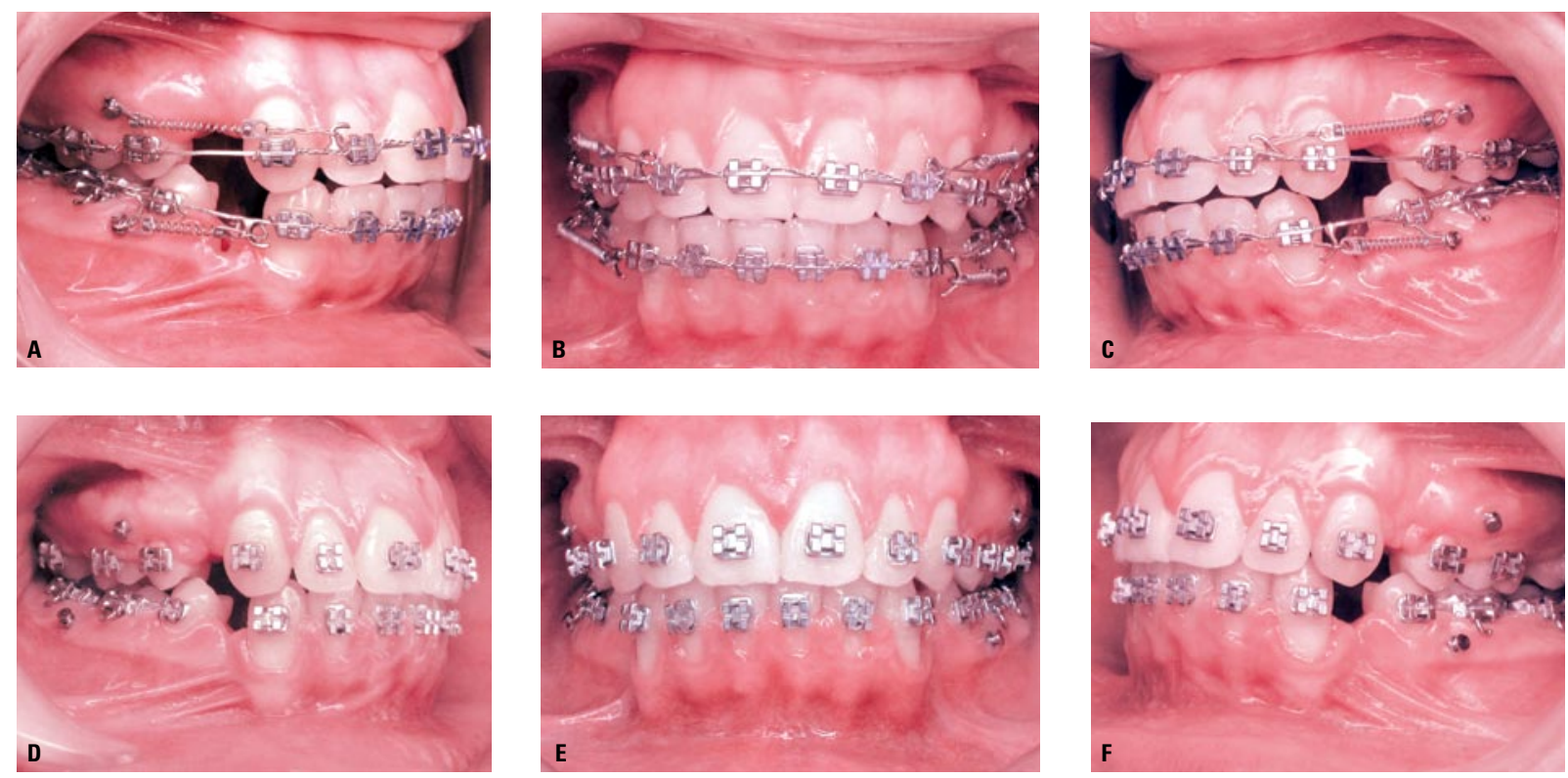

FIGURA 18 - Retração simultânea de caninos e incisivos: A, B, C) antes de iniciar a retração; D, E, F) seis meses após, com os espaços parcialmente fechados. 0 miniimplante inferior direito foi substituído por apresentar mobilidade.

ção da mecânica ou na eliminação da necessidade de colaboração por parte do paciente ${ }^{12,30,37}$.

Com esta finalidade, os miniimplantes devem ser inseridos entre canino e primeiro pré-molar ou entre primeiro e segundo pré-molares, por vestibular (Fig. 19). É recomendada, porém, sempre que possivel, a instalação de miniimplantes também por palatino ou lingual para que, durante a mesialização dos elementos dentários, tenha-se maior controle de rotações (Fig. 20). Quando necessária a colocação de miniimplantes por lingual, na mandibula, se houver presença de torus, esta seria a área mais indicada ${ }^{30}$.

\section{Intrusão de incisivos}

A utilização de ancoragem esquelética proporciona intrusão de incisivos sem efeitos indesejados em outras unidades podendo, em muitas situações, simplificar a mecânica ortodôntica. Os miniimplantes são especialmente úteis para intrusão dos incisivos, quando o paciente apresenta ausência de muitas unidades posteriores. 


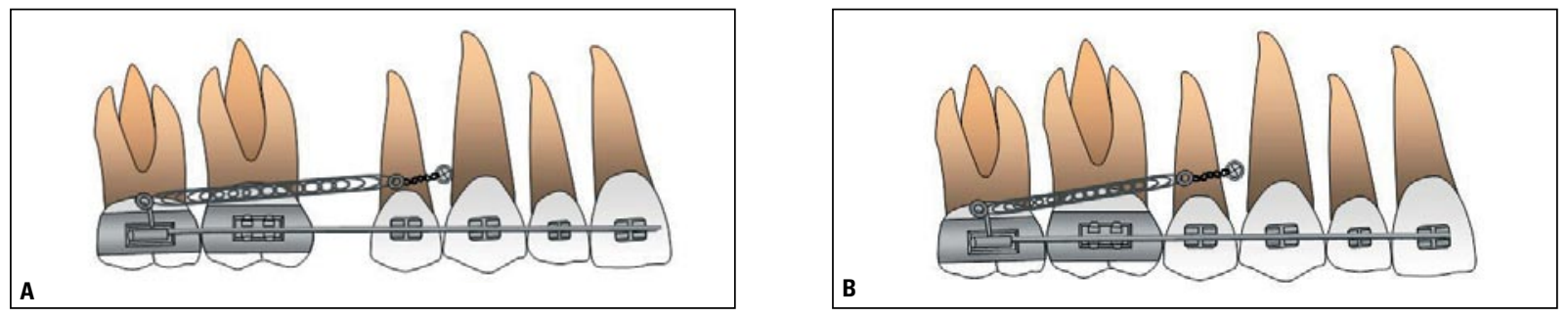

FIGURA 19 - Ilustração do uso de miniimplantes entre canino e primeiro pré-molar para a mesialização de molares: A) ativação do sistema; B) molares mesializados.
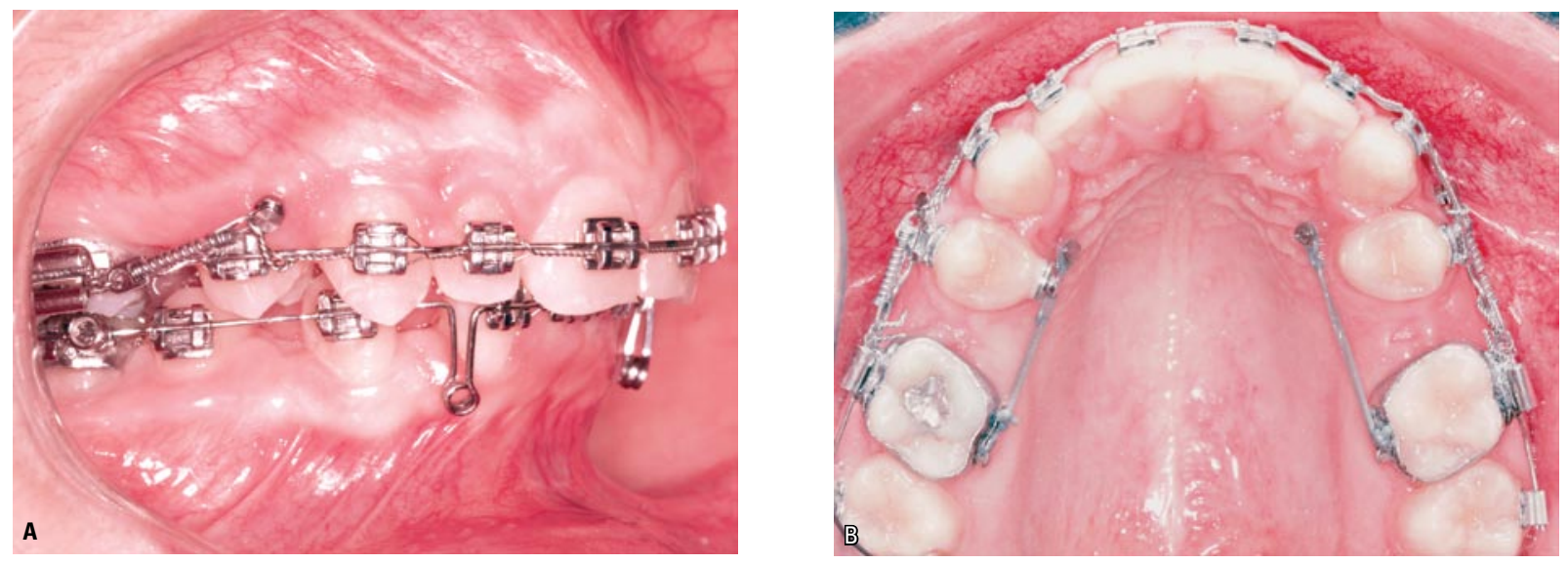

FIGURA 20 - Mesialização de molares: A) aplicação de força com mola NiTi por vestibular; B) aplicação de força com elastômero em cadeia por palatino.

A posição ideal para a instalação dos miniimplantes com a finalidade de intruir incisivos dependerá da inclinação destes. Em casos com incisivos verticais ou retro-inclinados, como na Classe II, $2^{a}$ divisão de Angle, pode-se utilizar um único miniimplante na linha média próximo à espinha nasal anterior (Fig. 21A). Para a intrusão de incisivos inferiores, o miniimplante deve ser posicionado o mais baixo possível, entre os centrais ${ }^{12}$. Nesta posição, a linha de força passará bem à frente do centro de resistência do conjunto, gerando um efeito de intrusão e proclinação das unidades dentárias superiores e inferiores. Caso não se queira a projeção destas unidades, seja na arco superior ou inferior, podem-se utilizar dois miniimplantes, posicionando-os entre centrais e laterais ou entre laterais e caninos, fazendo com que a linha de ação da força passe mais próxima do centro de resistência do conjunto formado pelos dentes que estão sendo movimentados ${ }^{6,26}$ (Fig. 21B).

\section{Intrusão de dentes posteriores}

A intrusão de molares é, talvez, o movimento mais difícil de se conseguir ortodonticamente. A literatura tem mostrado alguns resultados satisfatórios com a utilização de aparelhos extrabucais de puxada alta, mentoneiras verticais ou bite blocks. Porém, nem sempre é fácil conseguir do paciente a colaboração necessária para atingir o efeito desejado. Isto se deve ao grande desconforto físico e/ou estético que esses aparelhos podem causar.

Em alguns casos, quando se trata da intrusão de uma única unidade ou de um só lado da arco, seja por perda das unidades antagonistas, seja por assimetria no crescimento, a mecânica pode se tornar ainda mais complexa.

$\mathrm{O}$ número e a posição dos miniimplantes a serem instalados com a finalidade de intruir dentes posteriores podem variar bastante, a depender de quantas e quais unidades serão intruídas. Para a intrusão de uma ou mais unidades do mesmo 

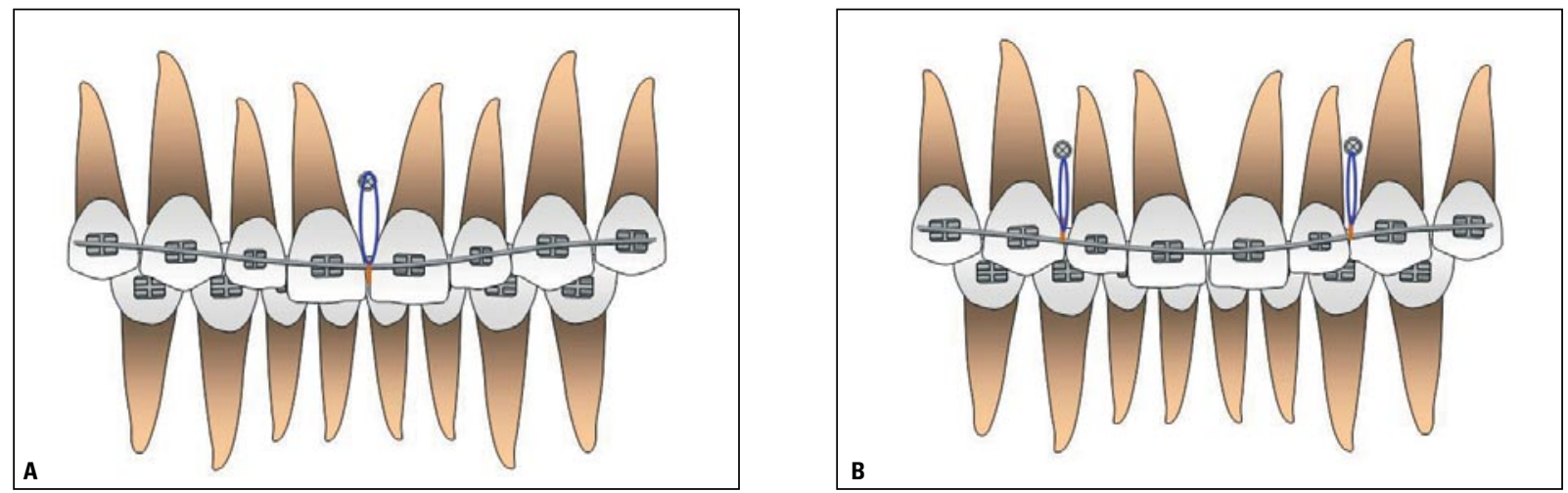

FIGURA 21 - Ilustração do posicionamento dos miniimplantes para a intrusão de incisivos superiores: A) entre incisivos centrais; B) entre incisivos laterais e caninos.

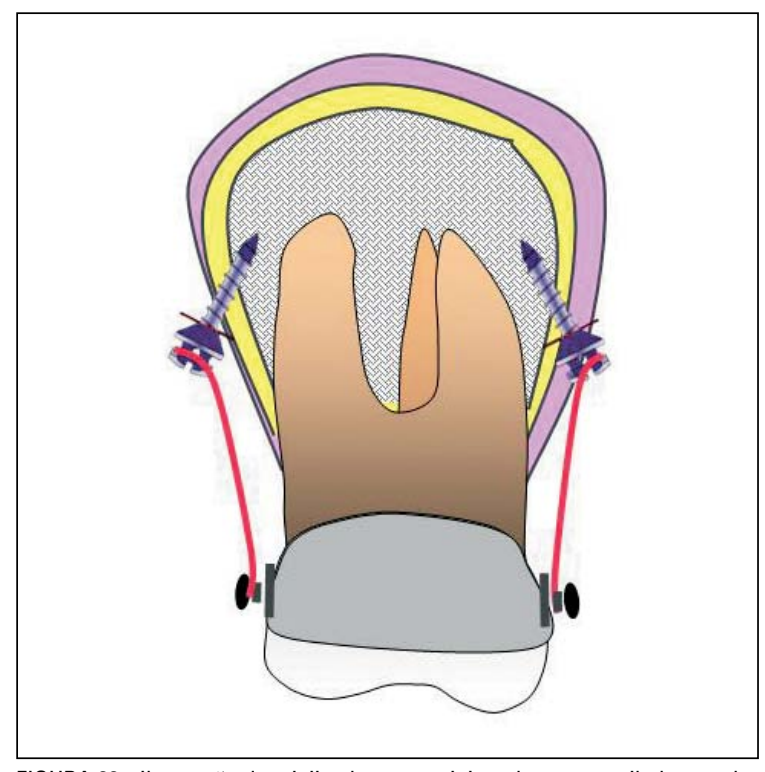

FIGURA 22 - Ilustração de miniimplantes posicionados por vestibular e palatino para intrusão de molares (visão proximal). Elásticos em cadeia unindo acessórios fixados na coroa e no miniimplante de cada lado, ativam o sistema. lado da arco, são necessários pelo menos dois miniimplantes, sendo um por vestibular e outro por palatino (Fig. 22). A aplicação de força tanto por vestibular quanto por palatino tem por objetivo conseguir a intrusão, controlando-se, ao mesmo tempo, a inclinação das unidades. Podem-se utilizar, ainda, caso se queira a intrusão de um número maior de dentes, três ou quatro miniimplantes, estrategicamente distribuídos ${ }^{3,37}$ (Fig. 23).

Se apenas um molar superior necessita de intrusão, dois miniimplantes são necessários: um na mesial por vestibular e outro na distal por palatino da unidade em questão. Os miniimplantes assim dispostos proporcionam um movimento dentário vertical controlado quando da ativação do sistema com elásticos sintéticos (Fig. 24).

Nos casos em que o ortodontista pretende intruir ambos os lados, como em tratamentos de
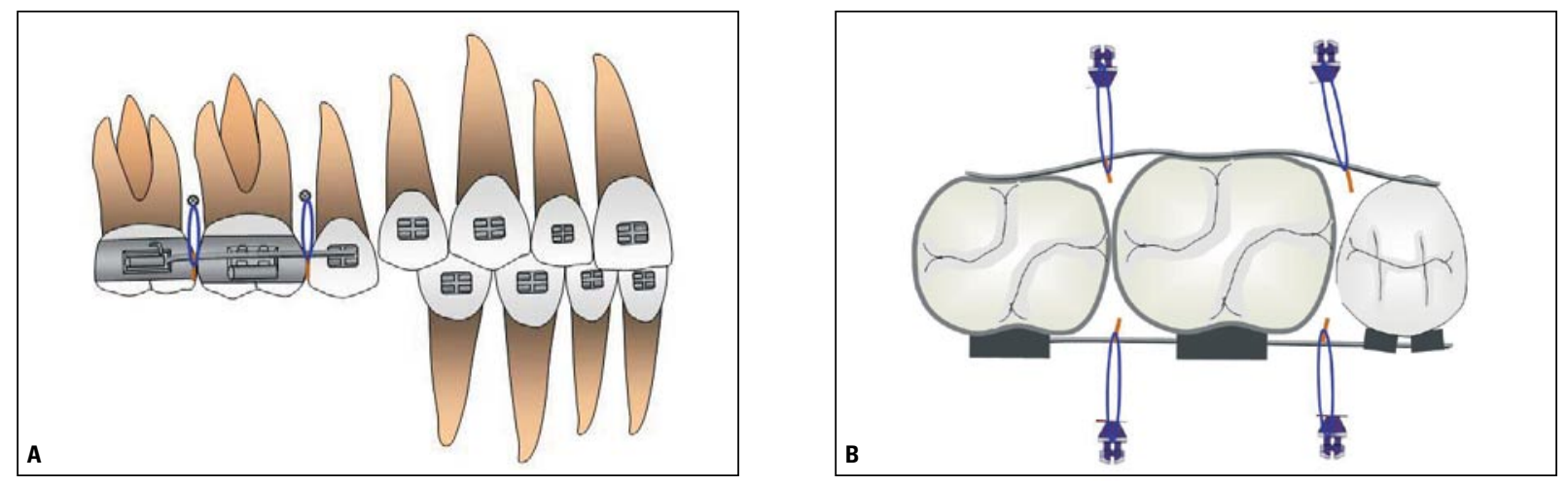

FIGURA 23 - Ilustração do posicionamento de miniimplantes para a intrusão de um grupo de dentes posteriores: A) visão vestibular; B) visão oclusal. 

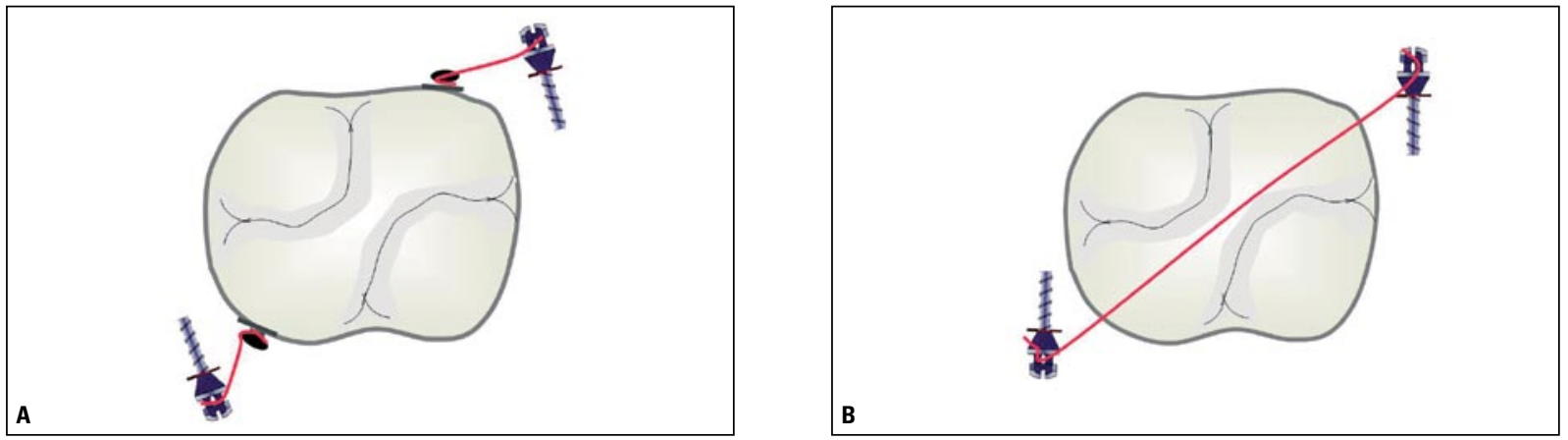

FIGURA 24 - Ilustração do uso de dois miniimplantes, mesial e distal, para a intrusão de um molar: A) ativação com elástico por vestibular e palatino, do miniimplante para cada face do dente; B) com elástico passando por oclusal.
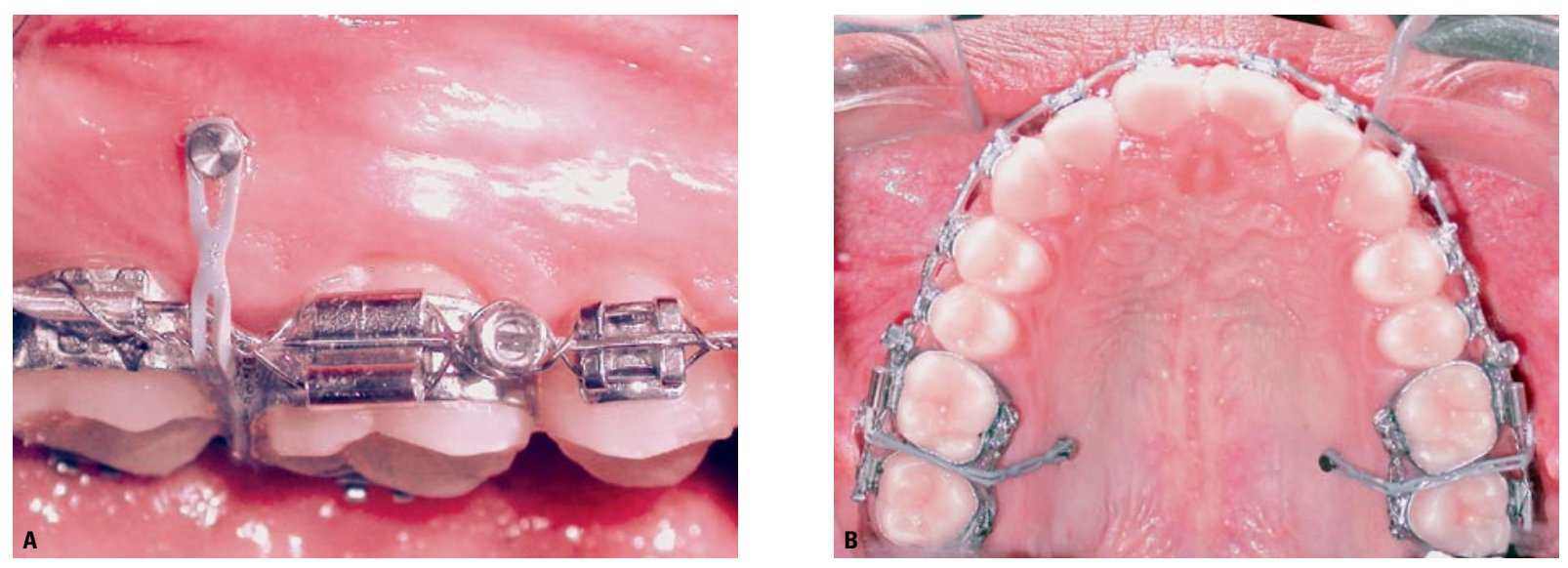

FIGURA 25 - Caso clínico com planejamento de intrusão de dentes posteriores para correção de mordida aberta anterior, com arco contínuo: A) visão lateral e B) visão do elástico passando de vestibular para palatino.
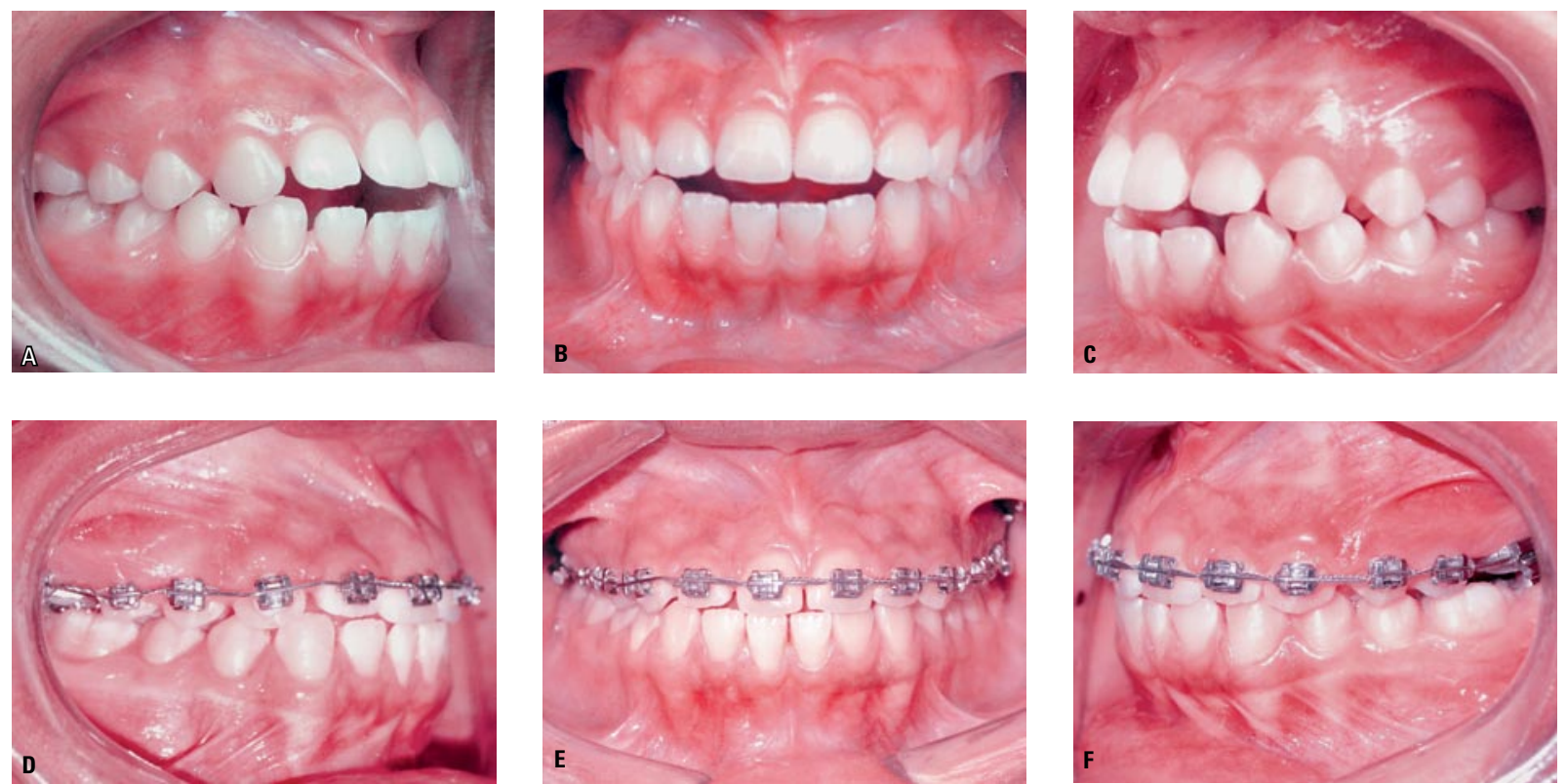

FIGURA 26 - Caso clínico com fechamento de mordida aberta anterior por intrusão das unidades posteriores com miniimplantes, utilizando metodologia ilustrada na figura 25. A, B, C) Fotografias iniciais; D, E, F) após a intrusão dos molares e fechamento da mordida. 
mordida aberta anterior por intrusão de molares, pode-se utilizar um miniimplante por vestibular e outro por palatino, entre o primeiro e o segundo molar (Fig. 25, 26).

Os miniimplantes destinados à intrusão devem ser instalados o mais apical possível, respeitando o limite da mucosa ceratinizada. Quanto mais distante das coroas dentárias, maior será a possibilidade de ativação, sendo que a inserção na região de mucosa livre pode favorecer uma inflamação local, comprometer sua estabilidade ou acontecer o seu encobrimento pelos tecidos moles. Carano et al. ${ }^{6}$ chamam a atenção, porém, que quanto mais apical estiver o miniimplante ortodôntico, mais perpendicular à cortical óssea ele deverá ser posicionado, evitando assim perfurações ao seio maxilar ${ }^{50}$.

Quando for necessária a instalação em região de mucosa alveolar não-ceratinizada, uma alternativa é instalar o miniimplante submerso com um fio de amarrilho, proporcionando ligação com o meio externo, de forma a tornar possivel a ativação desejada.

Para a intrusão de dentes posteriores, podem ser utilizados arcos contínuos ou segmentados. Quando os dentes encontram-se com um nivelamento razoável, deve-se usar arcos contínuos (Fig. 26). Em casos que apresentam extrusão de grupo de dentes por perda de antagonistas, resultando em alteração do plano oclusal, o segmento extruído deve ser movimentado com a utilização do arco segmentado (Fig. 23). Em ambos os casos, é recomendável a fixação de segmento de arco também por palatino, proporcionando maior controle da movimentação vertical.

\section{Correção do plano oclusal}

A inclinação do plano oclusal, freqüentemente encontrada em pacientes com perda de unidades dentárias, portadores de assimetrias faciais, disfunções musculares severas e algumas outras patologias localizadas, é também uma das difíceis condições oclusais a serem corrigidas na clínica ortodôntica. Esta condição, sem o auxílio de uma ancoragem esquelética, implica em extrema dificuldade mecânica ${ }^{6}$ (Fig. 27).

A utilização de miniimplantes para a intrusão de unidades dentárias que estejam desniveladas, comprometendo a inclinação do plano oclusal, pode significar a substituição de uma mecânica extremamente complexa por um recurso simples ${ }^{6}$.

\section{Distalização de molares}

A necessidade de distalização de molares é extremamente freqüente na clínica ortodôntica, sendo normalmente utilizada para a correção de más oclusões de Classe II e III de Angle, sem lançar mão de extrações dentárias. Existe na literatura a descrição de diversas técnicas visando este objetivo, sendo as principais os aparelhos extrabucais, distalizadores intrabucais e mecânicas de Classe II e III. Estes recursos apresentam como pontos negativos a falta de estética, a presença de efeitos indesejados nas unidades de ancoragem, além da necessidade de colaboração por parte do paciente.
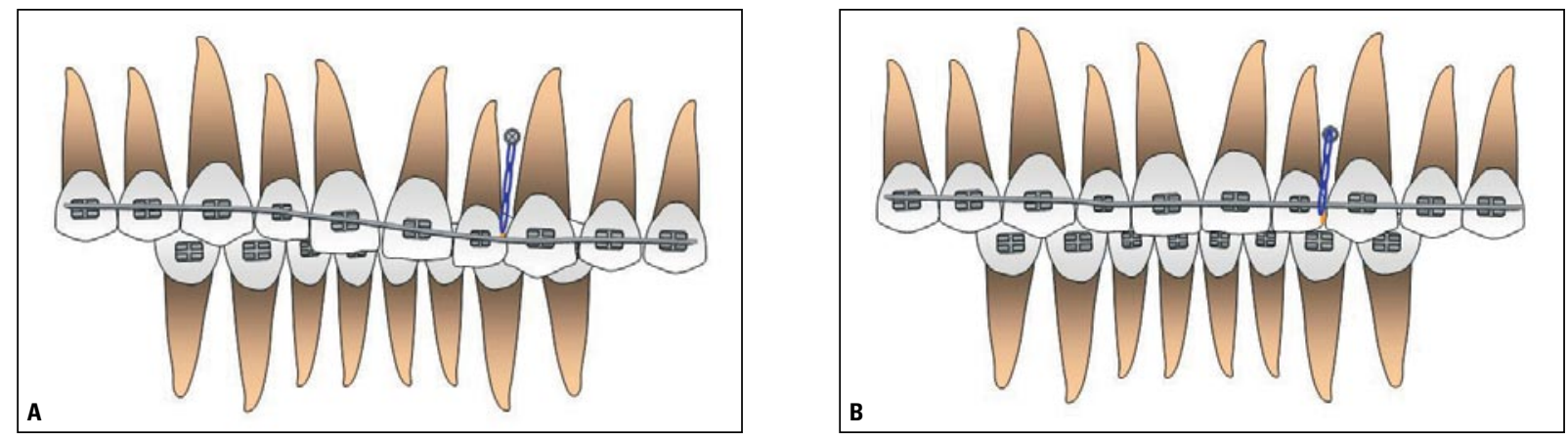

FIGURA 27 - A, B) llustração da utilização de miniimplante para a correção da inclinação do plano oclusal. 

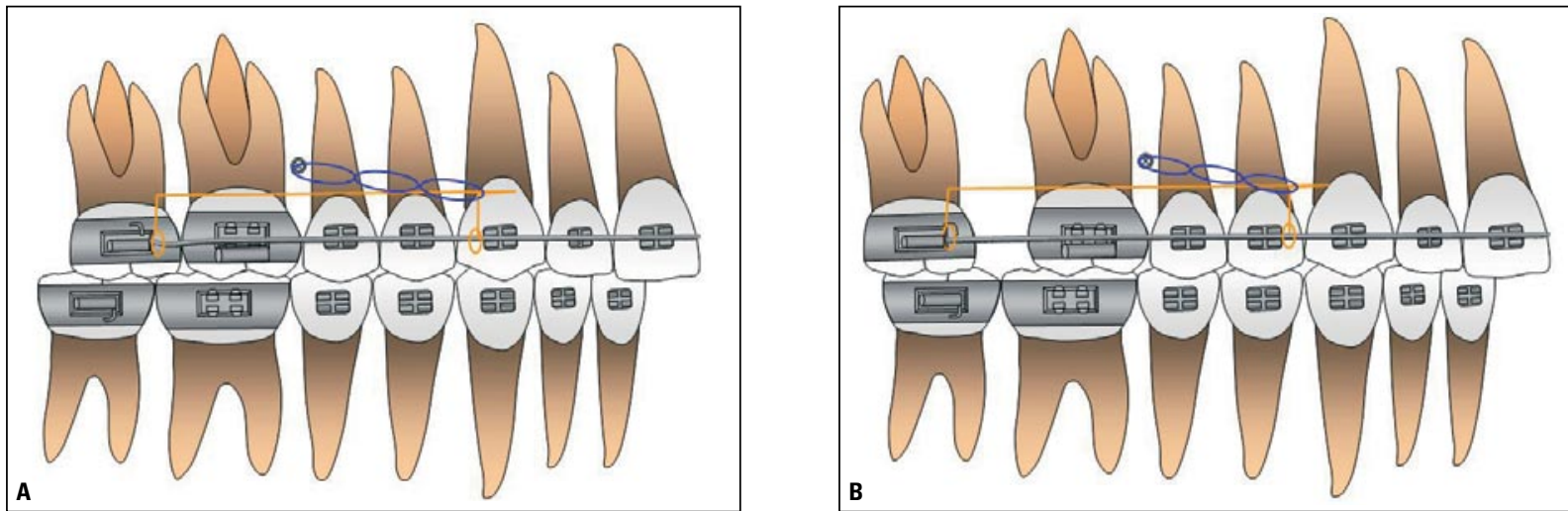

FIGURA 28 - A, B) llustração da utilização de miniimplantes para a distalização de molares através de sliding jigs e elastômeros em cadeia.

A utilização de miniimplantes para distalizar molares esbarra no problema da localização, uma vez que esses são normalmente posicionados entre raízes. O posicionamento dos miniimplantes entre o segundo pré-molar e o primeiro molar seria uma boa opção para este tipo de movimentação, sendo necessário utilizar-se sliding jigs ou molas abertas para transferir a força para uma região mais posterior $^{10}$ (Fig. 28, 29). Uma vez que a distalização de molares é, na grande maioria dos casos, seguida pela retração dos dentes a eles anteriores, torna-se necessária a remoção dos implantes para dar seqüência ao tratamento. Então, para a distalização de pré-molares e caninos pode-se programar a instalação de aparelhos auxiliares convencionais como recurso de ancoragem ou, se necessário, proceder a inserção de novos miniimplantes entre primeiros e segundos molares.

Alguns autores sugerem, para a distalização de molares, a utilização de um miniimplante na rafe palatina mediana, com a aplicação de força através de uma barra transpalatina ${ }^{21,28,31,37}$ (Fig. 30). A linha média do palato possui osso cortical de excelente qualidade. Porém, devido à presença da sutura óssea, o miniimplante para esta região deve ser mais espesso. Se constatada instabilidade primária após instalação nesta área, o DAT deve ser fixado adjacente à sutura ${ }^{31}$.

A aplicação de carga para a distalização de molares acima descrita é de difícil controle, pois o ponto de aplicação de força acima do centro de resistência das unidades dentárias leva a uma inclinação destas, com distalização mais acentuada da porção radicular. Esta condição se agrava em palatos mais profundos.

Neste caso, a utilização de dois miniimplantes no rebordo alveolar palatino, de forma a obter uma linha de ação de força mais próxima do centro de resistência dos molares, evitando assim inclinação destas unidades, parece ser uma boa alternativa. Em adição, a localização de miniimplantes no palato elimina a necessidade de remoção destes para a retração de dentes localizados anteriormente aos DATs, como acontece quando são instalados por vestibular (Fig. 31).

\section{Verticalização e desimpacção de molares}

A verticalização dos molares inferiores está recomendada quando acontece inclinação acentuada destes dentes, devido à perda de unidades adjacentes ou em casos de impactação de segundos molares inferiores. Dependendo do grau de angulação que o dente em questão se encontre, e levando em consideração o seu volume radicular, este tipo de movimentação pode tornar-se difícil. A possibilidade de utilização dos miniimplantes com carga imediata tem modificado a abordagem clínica e biomecânica deste problema. Seja para evitar movimentações indesejadas nas unidades de ancoragem, seja para impedir a extrusão do 

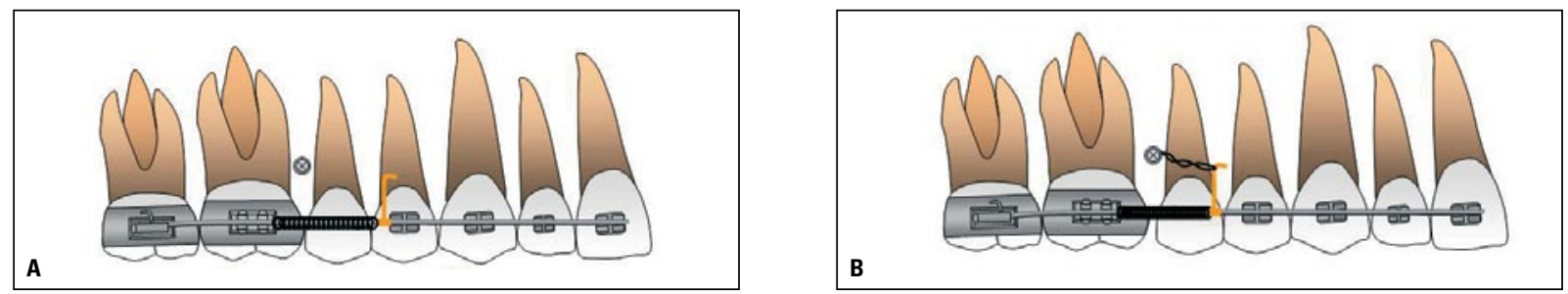

FIGURA 29 - A, B) llustração da utilização de miniimplantes para a distalização de molares através de mola aberta inserida no arco. Ativação realizada com amarrilho metálico do DAT para o gancho deslizante comprimindo a mola.
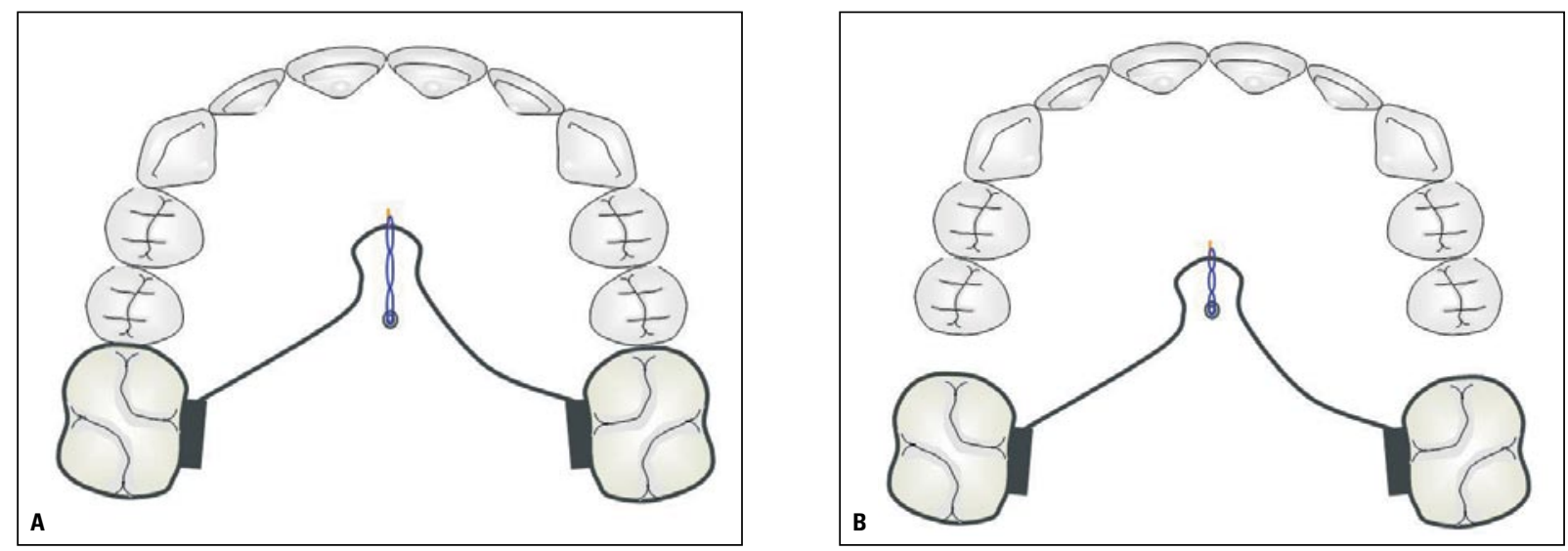

FIGURA 30 - Ilustração de distalização de molares com miniimplante na linha média do palato, utilizando barra transpalatina: A) início da ativação; B) molares distalizados.
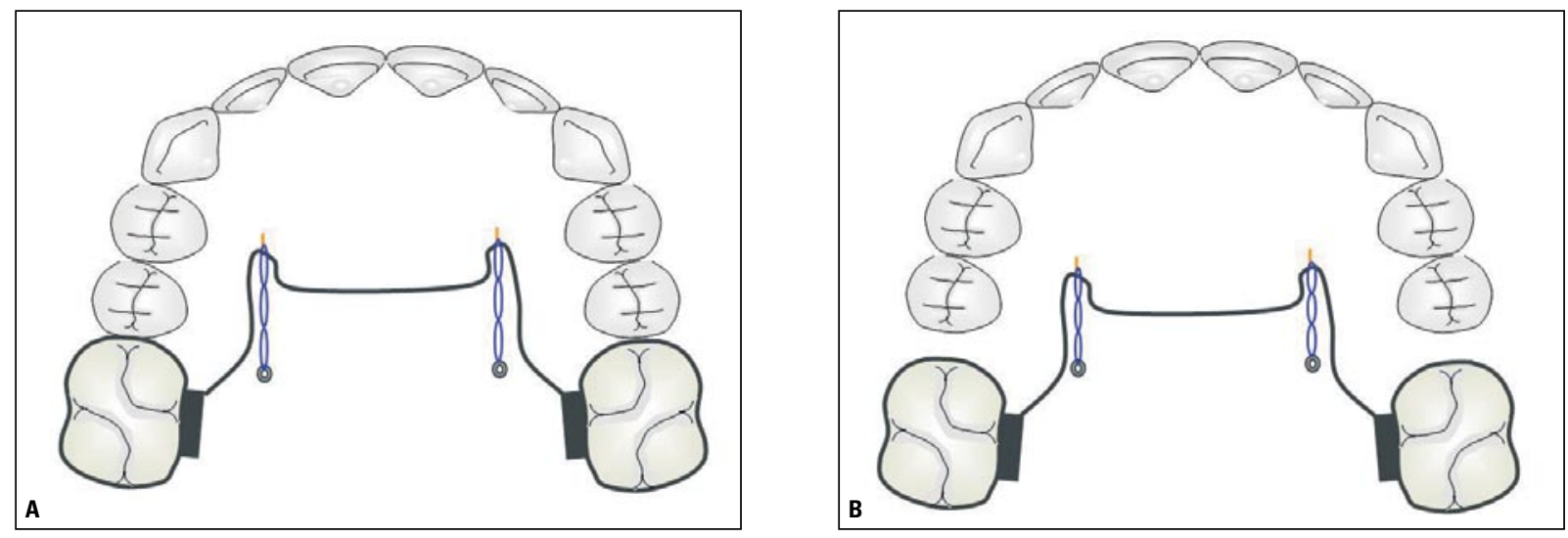

FIGURA 31 - Ilustração de distalização de molares com dois minimplantes no rebordo alveolar palatino, utilizando barra transpalatina: A) início da ativação; B) molares distalizados.

próprio molar, a utilização de um ou mais miniimplantes ortodônticos pode ser de grande auxílio ${ }^{22}$.

Uma das opções para a inserção de miniimplantes com o intuito de desimpactar e/ou verticalizar molares é a região retromolar (Fig. 32). Neste caso, o ponto de ancoragem fica posicionado distalmente da unidade em questão, ocorrendo assim uma abertura de espaço. A ativação ortodôntica pode ser realizada através de molas fechadas, elásticos em cadeia ou em fio, do implante a um acessório 

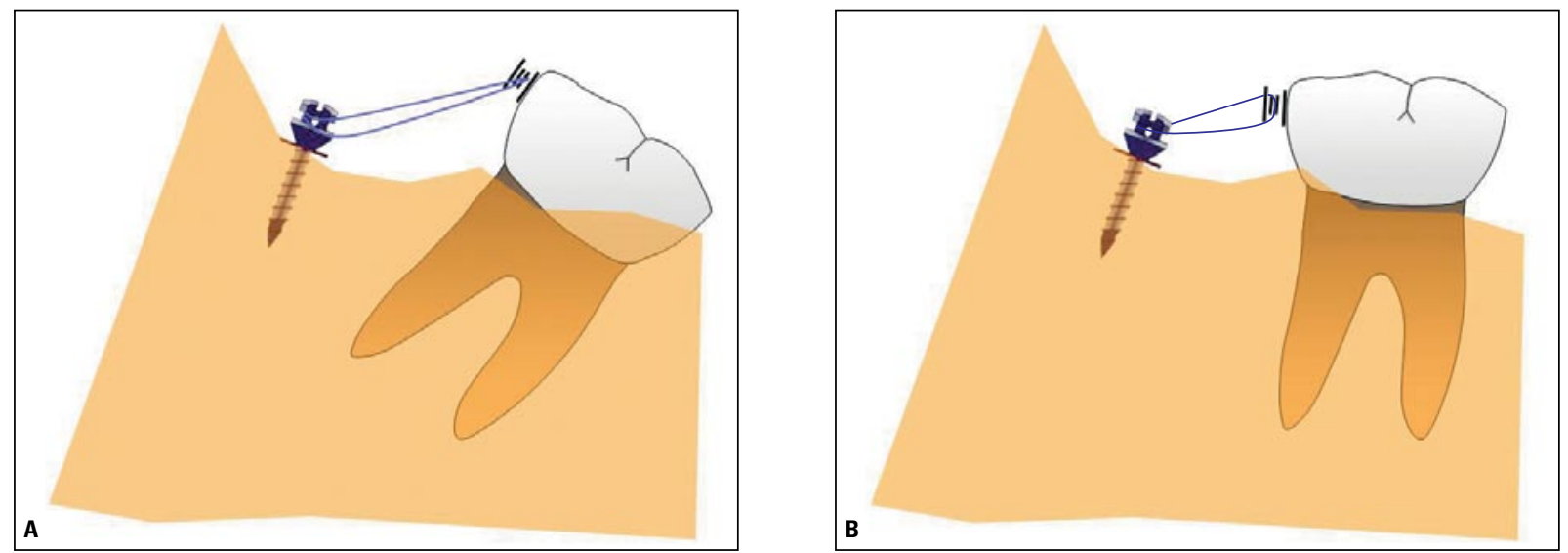

FIGURA 32 - Ilustração do uso de miniimplante na região retromolar para a verticalização de molar com abertura de espaço: A) ativação do sistema através de elásticos; B) molar verticalizado.
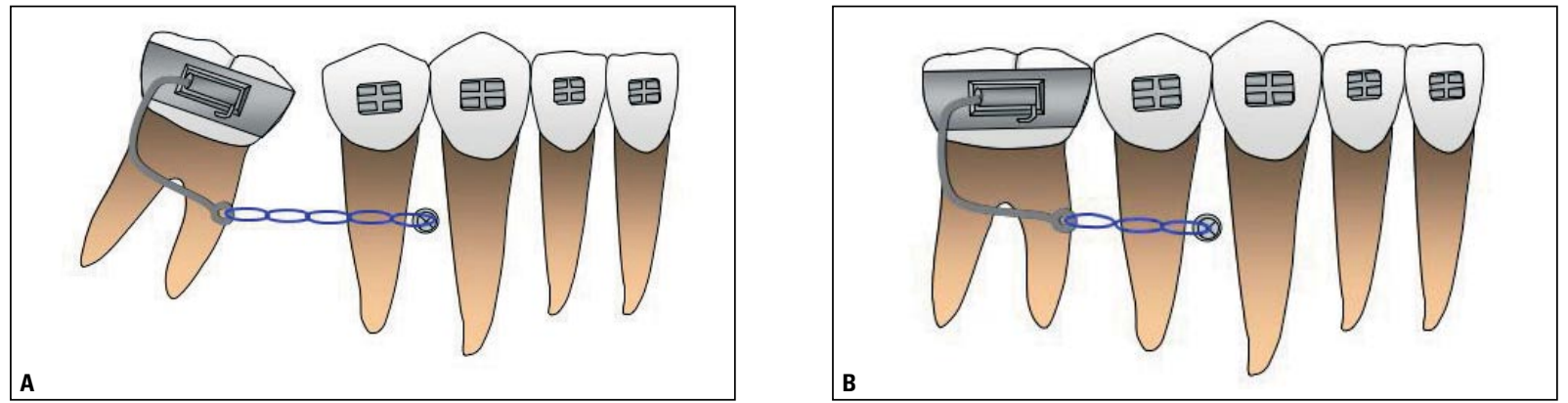

FIGURA 33 - Ilustração da verticalização de molar inferior com miniimplante entre pré-molares e fio inserido na distal do tubo: A) ativado com elastômero em cadeia e B) após a mesialização da unidade.

fixado, onde for possivel (faces distal, oclusal ou mesial), no dente a ser movimentado ${ }^{22,37}$. Não existindo espaço para a instalação do dispositivo, devido à ausência de mucosa ceratinizada na região, o miniimplante pode ficar submerso e se utilizar um fio de amarrilho metálico como elo de ligação com o meio externo, de forma a possibilitar a ativação do sistema.

Quando a intenção é verticalizar um molar, fechando o espaço, pode-se lançar mão de um miniimplante numa região mais anterior. Neste caso, o ponto de aplicação de força poderá ser um fio inserido por distal no braquete do molar, que passe abaixo do seu centro de resistência, devendo-se, neste caso, ter atenção especial com a profundidade do vestíbulo, evitando-se desconforto por parte do paciente ${ }^{37}$ (Fig. 33).

\section{Correção de mordida cruzada posterior}

O desvio no eixo de irrupção dentária pode levar a uma mordida cruzada posterior. Quando os dentes superiores e inferiores apresentam desvios em suas inclinações axiais, pode-se lançar mão de elásticos intermaxilares para correção do problema. Estes, porém, além de apresentarem resultante de força extrusiva, o que não é desejável para alguns casos, necessitam da colaboração do paciente ${ }^{47}$.

Para descruzamento de mordida posterior, os miniimplantes devem ser posicionados da seguinte forma: para a correção de mordida cruzada lingual, utiliza-se um DAT por vestibular na maxila e outro por lingual na mandíbula (Fig. 34); para a correção de mordida cruzada vestibular, utiliza-se um DAT no palato e outro por vestibular na mandíbula (Fig. 35). Desta forma evita-se o efeito extrusivo e a neces- 


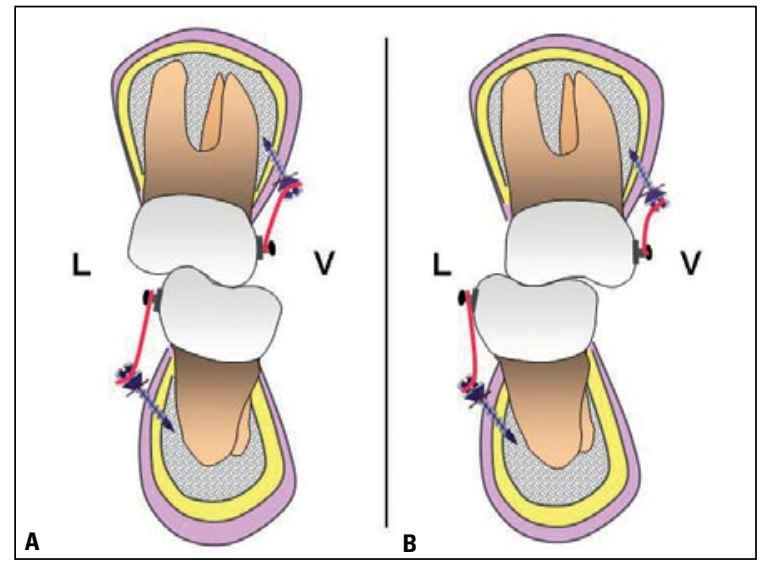

FIGURA 34 - Ilustração da correção de mordida cruzada posterior lingual: A) miniimplantes instalados por vestibular na maxila e lingual na mandíbula, $\mathrm{e}$ B) mordida cruzada corrigida, após ação dos elásticos.

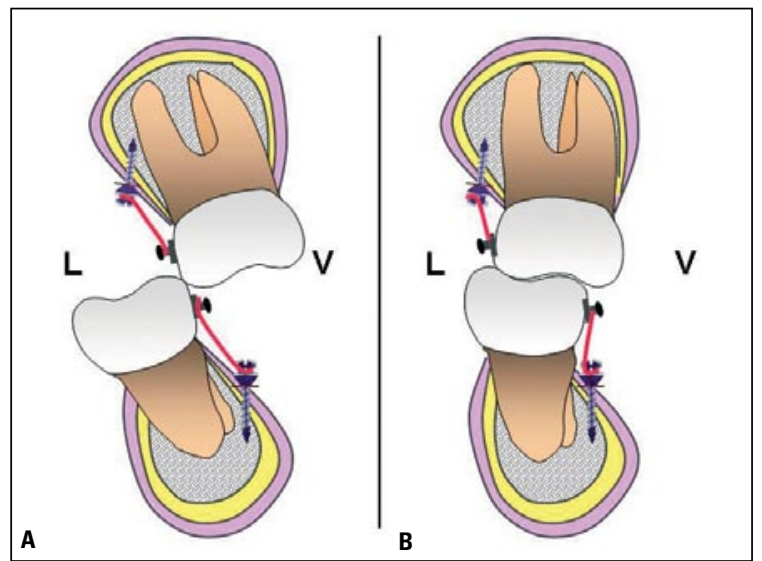

FIGURA 35 - Ilustração da correção de mordida cruzada posterior vestibular: A) miniimplantes instalados no palato e vestibular mandíbula, e B) mordida cruzada corrigida, após ação dos elásticos.

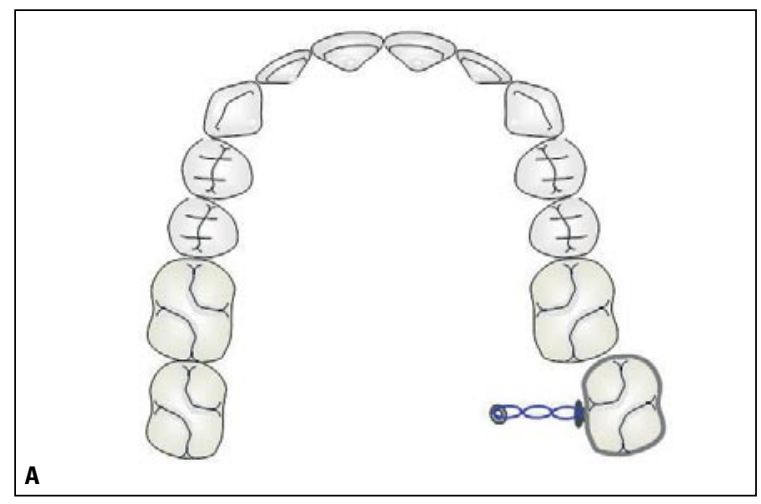

FIGURA 36 - llustração de correc
ação do elástico em cadeia.

sidade de colaboração do paciente. Caso apenas uma unidade dentária esteja com sua inclinação axial incorreta, utiliza-se um ou dois miniimplantes no lado contrário à inclinação. Este recurso pode também representar uma opção para correção da inclinação vestibular dos segundos molares superiores, sem efeito de extrusão, mesmo que estes não estejam em mordida cruzada (Fig. 36).

\section{Tracionamento de dentes inclusos}

O tracionamento de dentes inclusos pode ser realizado de diversas maneiras como, por exemplo, através de arcos segmentados, arcos contínuos super-elásticos ou aparelhos removiveis associados ao uso de elásticos. Nestes casos, ou faz-se necessária a colaboração do paciente ou a montagem do aparelho fixo.

O miniimplante ortodôntico, estrategicamente instalado, pode proporcionar o tracionamento de dentes inclusos, sem necessidade de montagem do aparelho fixo e sem o conseqüente movimento indesejado das unidades de ancoragem. Com a unidade dentária já presente na cavidade bucal a aparelhagem fixa deve ser instalada para a correção de possíveis giros e inclinações ${ }^{6,37,45}$ (Fig. 37). Neste caso, a grande vantagem é a diminuição do tempo de tratamento com aparelho fixo em boca.

O posicionamento do miniimplante deve ser pla- 


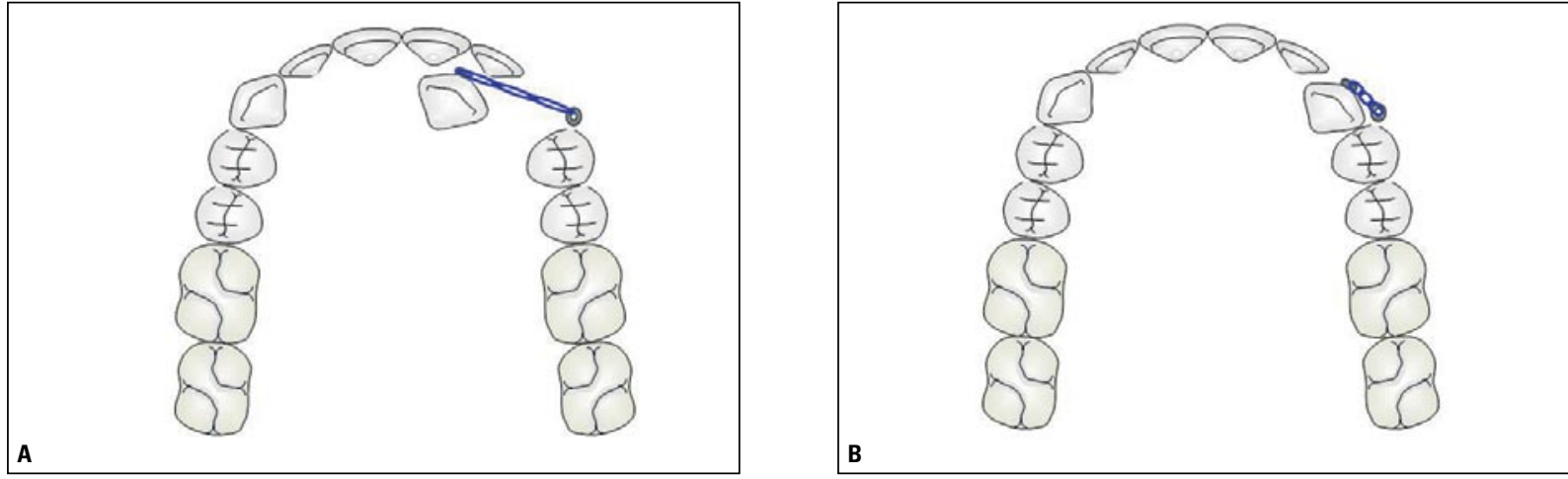

FIGURA 37 - Ilustração de tracionamento de canino com uso de miniimplante: A) ativação do sistema com elástico e B) canino melhor posicionado no arco.
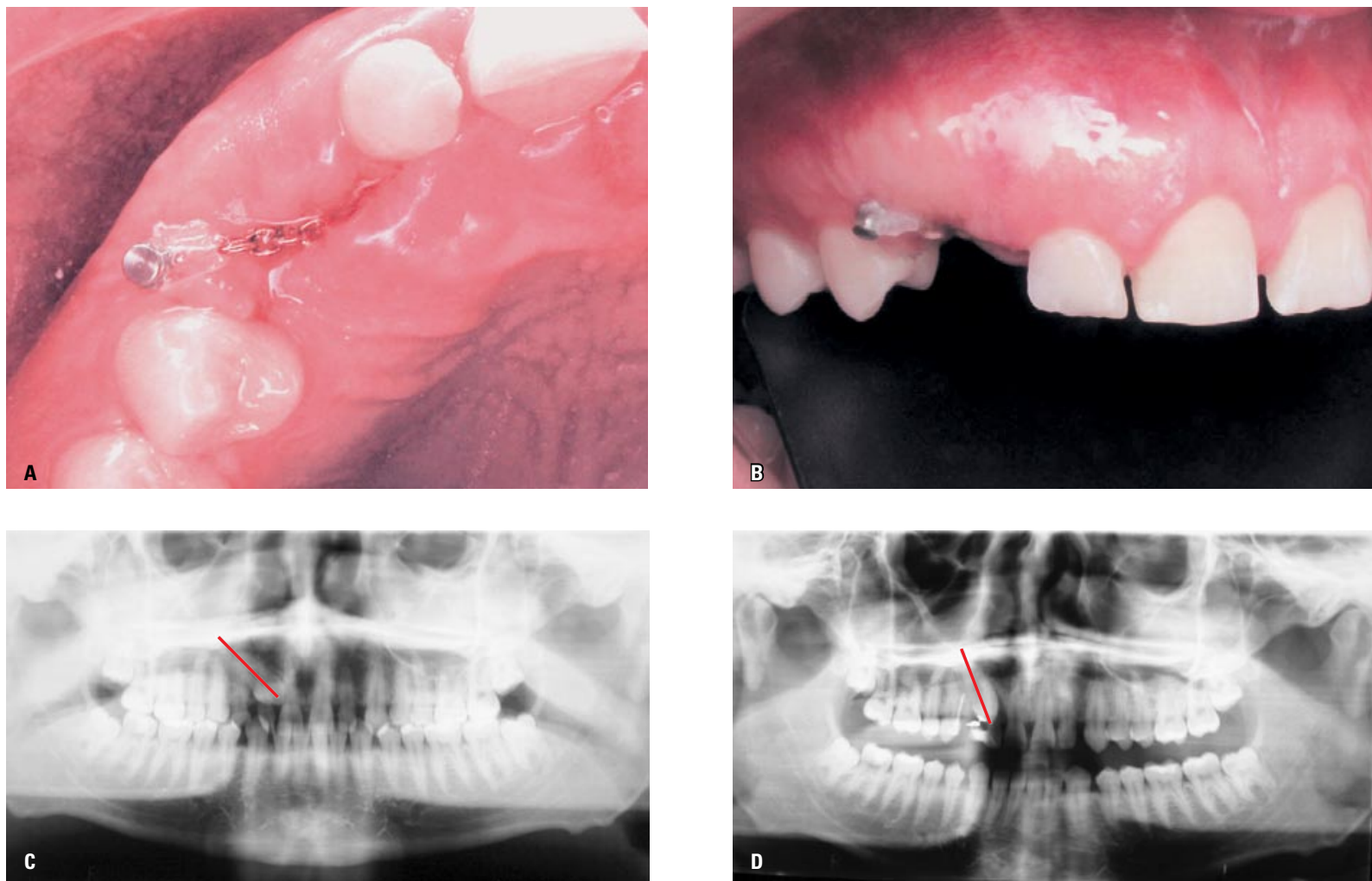

FIGURA 38 - Caso clínico com início de tracionamento de canino incluso: A, B) ativação do sistema com corrente e elástico em fio; C, D) radiografias evidenciando melhora no posicionamento da unidade dentária.

nejado de acordo com a localização do dente incluso. Para o paciente ilustrado na figura 38, foi projetada a instalação do dispositivo de ancoragem na mesial do primeiro pré-molar, o mais baixo possível.

\section{Correção de linha média}

Casos que apresentam desvio de linha média dentária e ausência de dentes posteriores, para servirem como ancoragem, podem se tornar um problema do ponto de vista mecânico para o ortodontista. Nestas situações, a instalação de um miniimplante distalmente ao espaço a ser utilizado para a correção pode simplificar, ou mesmo possibilitar a movimentação dentária no sentido desejado (Fig. 39). 


\section{Elásticos intermaxilares}

Os miniimplantes posicionados em um dos arcos podem ainda ser de grande valia como recurso de ancoragem para movimentação dentária no arco

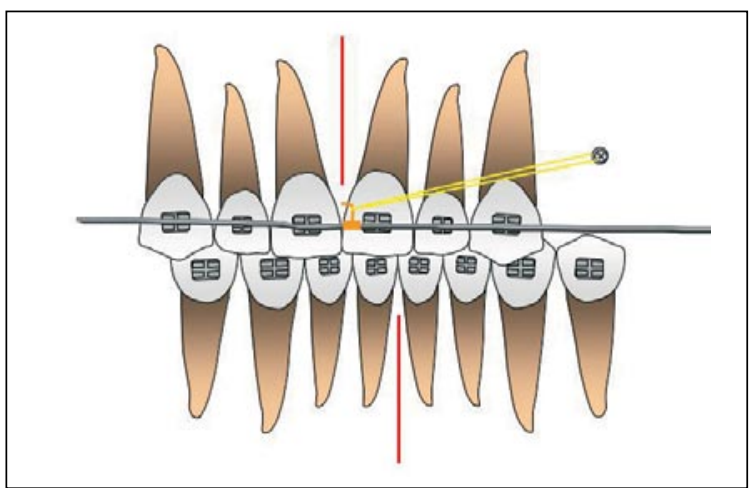

FIGURA 39 - llustração do uso de miniimplantes para a correção da linha média dentária superior, quando da ausência de dentes posteriores. antagonista. Pode-se lançar mão dos elásticos intermaxilares, com diversas finalidades, apoiados aos DATs, seja para utilização de mecânicas verticais, de Classe II, de Classe III, para a distalização de dentes posteriores ou retração de anteriores, sem efeito indesejável sobre o arco oposto $^{6,9}$ (Fig. 40).

\section{ATIVAÇÃO DO SISTEMA}

A ancoragem obtida com os miniimplantes pode ser classificada como direta ou indireta. $\mathrm{Na}$ primeira, a carga é aplicada diretamente no dispositivo (Fig. 41-A), e na última, o miniimplante é utilizado para a imobilização de um dente, ou grupo de dentes, e sobre estes a força é aplicada (Fig. 41B).

Para que a carga possa ser aplicada, o DAT deve apresentar estabilidade primária e condições de suportar os estresses e as tensões a que será
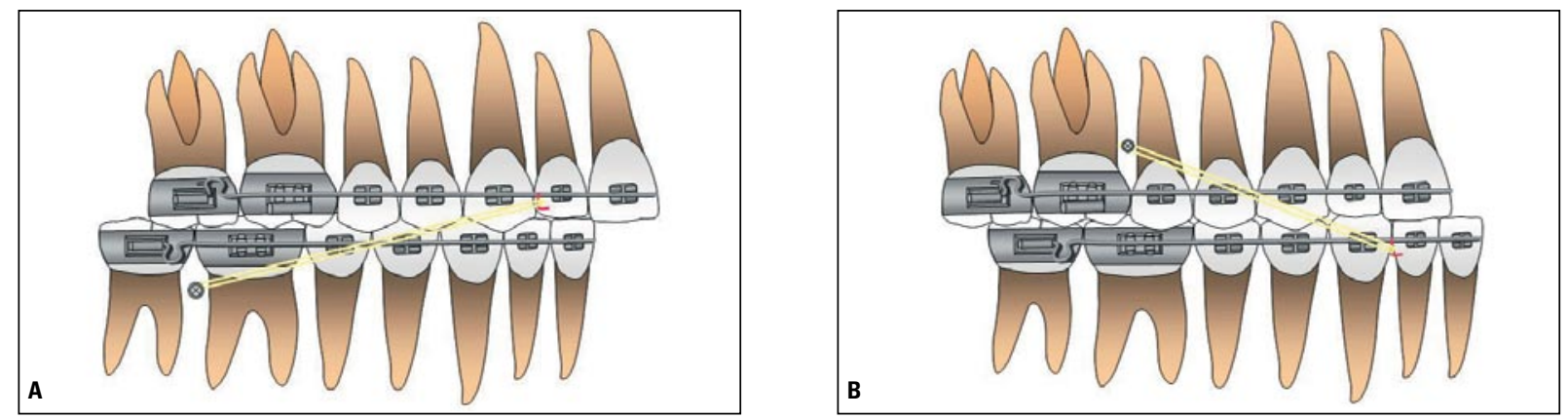

FIGURA 40 - Ilustração do uso de miniimplantes servindo de suporte para a aplicação de mecânicas de Classe II (A) e Classe III (B).
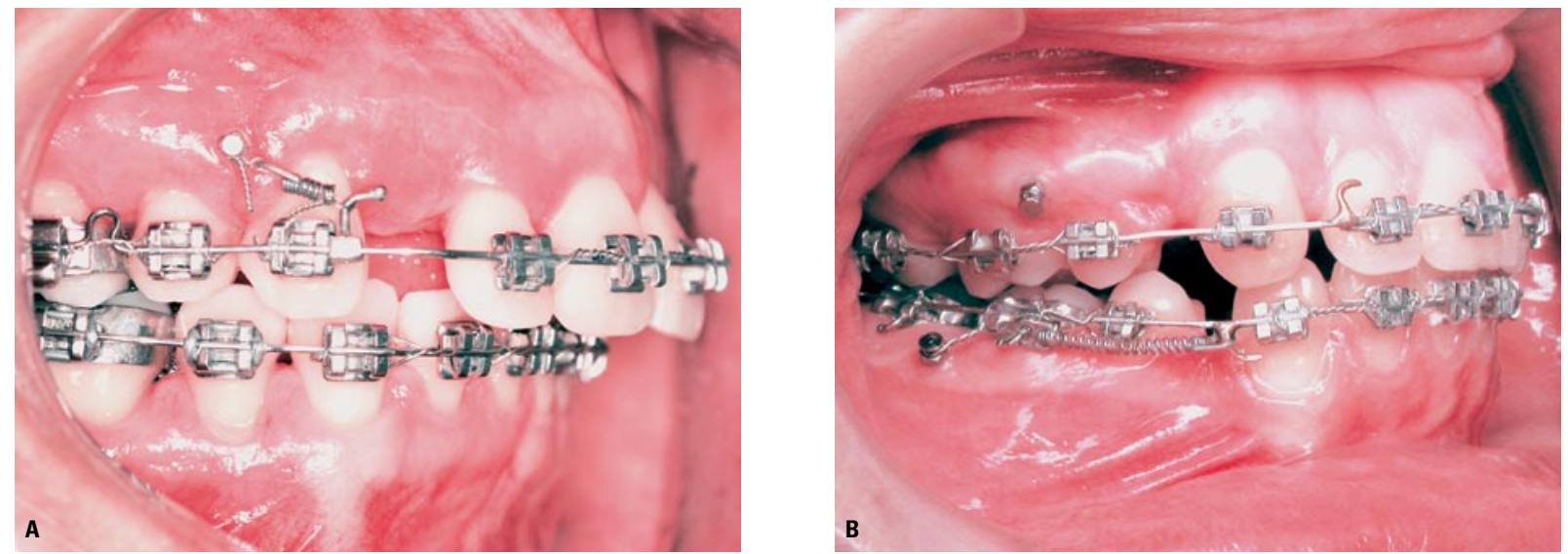

FIGURA 41 - Ativação da retração dos dentes anteriores utilizando miniimplante: A) ancoragem direta aplicada para a retração do canino; B) ancoragem indireta utlilizada para retração em massa dos dentes anteriores inferiores. 
submetido ${ }^{19}$.

A aplicação de carga sobre o miniimplante ortodôntico pode se dar de forma imediata ${ }^{2,3}$ após um período de cicatrização de $14 \operatorname{dias}^{27,35,36,41,46,49}$ ou após o período de osseointegração, para os que se aplicam ${ }^{9,10,26}$. Há, porém, na literatura, certa controvérsia quanto à época ideal desta ativação no que diz respeito a um aumento da estabilidade ${ }^{36}$.

O aguardo de duas semanas seria para a cicatrização dos tecidos periimplantares, evitando-se assim inflamação que poderia interferir na estabilidade do miniimplante. Há relatos na literatura, porém, que, baseando-se em experiências clínicas, afirmam ser este o período de ativação que tem demonstrado o maior índice de falha dos miniimplantes ${ }^{36}$.

A aplicação de força imediatamente após a ci-
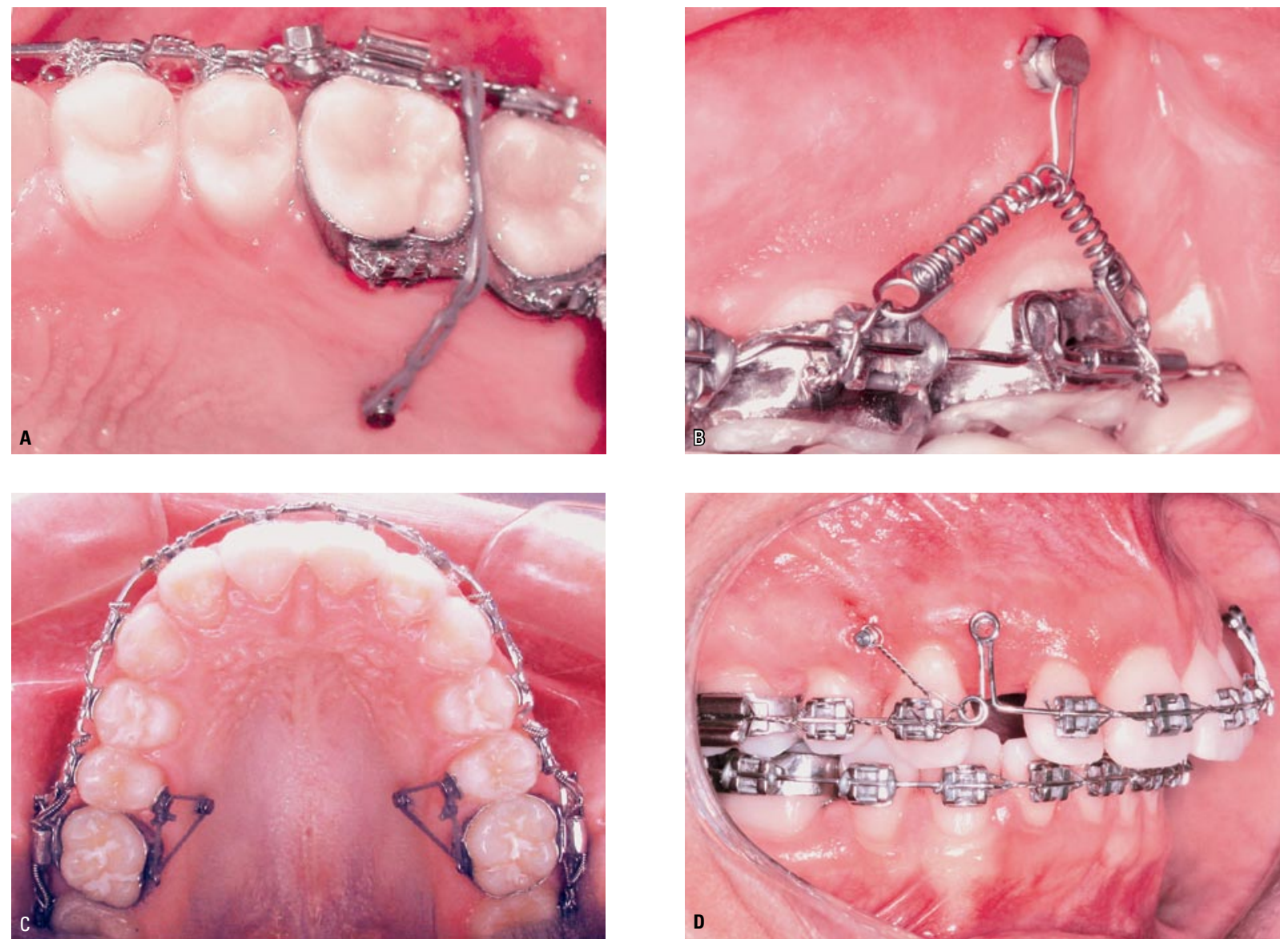

FIGURA 42 - Recursos para ativação do sistema: A) elastômero em cadeia; B) mola de NiTi; C) elástico em fio; D) alça vertical. 
tipo de movimento desejado. Quanto maior o número de dentes maior a carga necessária para o deslocamento destes no osso. Por outro lado, para movimentos de intrusão, as forças devem ser mais leves que para movimentos de distalização, por exemplo.

Apesar de alguns autores recomendarem a aplicação de forças mais leves nas primeiras ativações $^{6,37,39}$, nossa experiência clínica revela que pode-se ativar o sistema imediatamente após a instalação do miniimplante, de acordo com a necessidade, com carga de até $250 \mathrm{~g}$ sobre cada dispositivo, sem comprometimento da estabilidade deste. Contudo, recomendamos que se houver necessidade do aumento da carga isto só deverá ser realizado após 30 dias da ativação inicial. É importante salientar que uma vez definida a força necessária para obtenção do movimento em questão, esta deve ser aferida com dinamômetro.

Uma grande variedade de intensidades de força, entre 50 e $400 \mathrm{~g}$, aparece na literatura, sendo aplicadas aos miniimplantes sem comprometimento da estabilidade ${ }^{30,48}$. A carga máxima a ser aplicada deve ser proporcional à área de superfície de contato entre o implante e o tecido ósseo. Esta deve ser determinada pelo comprimento, diâmetro e forma do implante ${ }^{19}$. De acordo com Kyung et al. ${ }^{29}$, os miniimplante suportam cargas de até $450 \mathrm{~g}$, sendo que em Ortodontia as forças intrabucais desejadas não excedem $300 \mathrm{~g}$.

Para a ativação do sistema podem ser utilizados elásticos de borracha ou sintéticos, molas de aço inoxidável ou de Niti, além de alças confeccionadas com diferentes materiais. Mah e Bergstrand $^{36}$ defendem que é preferível o uso de molas, devido à liberação contínua de força. Os elásticos são de fácil manuseio clínico, oferecem conforto ao paciente, porém, em função da degradação da força e das alterações sofridas no meio bucal, o período entre as ativações deve ser de, aproximadamente, 15 dias, para que a carga seja mantida (Fig. 42).

\section{COMPLICAÇÕES}

Apesar dos excelentes resultados alcançados em relatos clínicos, a utilização dos miniimplantes ortodônticos de maneira rotineira ainda depende de comprovação científica. A realização de estudos prospectivos longitudinais controlados poderá fornecer índices de sucesso a curto, médio e longo prazos, além de elucidar de maneira pormenorizada os principais fatores de risco e complicações decorrentes da utilização desta técnica. Descreveremos a seguir as principais complicações clínicas relacionadas aos miniimplantes.

\section{Perda de estabilidade}

Os DATs proporcionam uma ancoragem estável para a movimentação dentária, porém, após a aplicação da força ortodôntica nem sempre permanecem absolutamente fixos como os implantes osseointegráveis. Liou, Pai e $\operatorname{Lin}^{35}$, ao avaliarem a estabilidade de miniimplantes em humanos, após aplicação de cargas, constataram pequenos deslocamentos. Para evitar que estes dispositivos atinjam algum órgão vital, os autores recomendaram cuidado no planejamento, principalmente quanto à avaliação do espaço entre as raízes, distância de forame, nervos principais e vasos sanguíneos.

A perda de estabilidade do miniimplante é a complicação mais freqüente e pode ocorrer previamente, no momento ou após a ativação ortodôntica $^{23,42}$. Usualmente está relacionada com a baixa estabilidade primária obtida no momento da cirurgia, aplicação de força ortodôntica excessiva ou ainda devido à inflamação dos tecidos periimplantares, gerada por higienização deficiente ${ }^{39}$. Por essa razão, deve-se verificar a estabilidade do miniimplante a cada consulta.

Uma vez detectada clinicamente a mobilidade do miniimplante ortodôntico, o mesmo deverá ser substituído e o diagnóstico do agente etiológico que levou à perda deverá nortear o novo procedimento cirúrgico para evitarem-se futuros problemas.

Para minimização da ocorrência deste tipo de complicação, a técnica cirúrgica, buscando alta 
estabilidade primária, e orientação rigorosa da higiene periimplantar, conforme descritas previamente neste artigo, devem ser seguidas.

Miyawaki et al. ${ }^{39}$, ao avaliarem a estabilidade de miniimplantes com diferentes diâmetros, constataram que a ocorrência de mobilidade de implantes instalados na cortical vestibular estava relacionada com um diâmetro menor ou igual a $1 \mathrm{~mm}$, inflamação do tecido perimplantar e com a cortical óssea delgada, presente em pacientes com plano mandibular elevado. Não foi observada correlação positiva entre taxa de sucesso e comprimento do miniimplante, tipo de cirurgia, carga imediata de até $2 \mathrm{~N}$, local de instalação, idade e gênero.

Devido à ausência de trabalhos longitudinais bem controlados, as verdadeiras taxas de sobrevivência e sucesso desta técnica aplicada a diferentes situações clínicas ainda precisam ser definidas cientificamente, sendo que Cheng et al..$^{8}$ sugerem $89 \%$ através de estudo retrospectivo, Mah e Bergstrand $^{36}$ relatam sucesso entre 65 a $85 \%$ e Fritz, Ehmer e Diedrich ${ }^{20}$ de $70 \%$.

A perda de estabilidade do miniimplante é caracterizada clinicamente pela movimentação recíproca do mesmo em direção à unidade ativa e está relacionada à sensibilidade dolorosa e mucosite periimplantar.
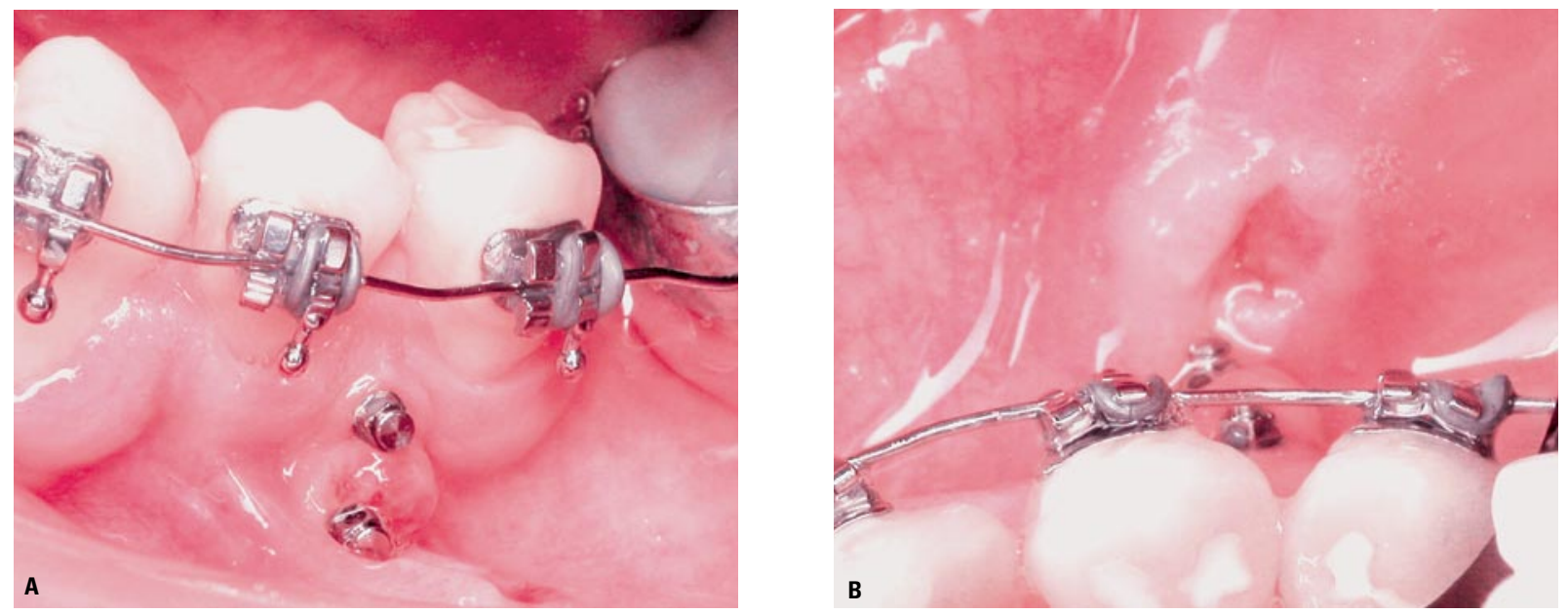

FIGURA 43 - A) Mucosite causada por instalação de miniimplante em mucosa não-ceratinizada; B) Lesão de mucosa causada por trauma da cabeça do miniimplante.

\section{Mucosite periimplantar}

A mucosite periimplantar é definida como uma patologia inflamatória restrita ao compartimento de tecidos moles periimplantares, de origem bacteriana e relacionada à higiene deficiente. A falta de controle desta condição poderá levar à perda do miniimplante (Fig. 43A).

Autores como Laboissière Jr. et al. ${ }^{33}$; Nascimento, Araújo e Bezerra ${ }^{41}$ recomendam o controle bacteriano através de protocolo rígido de higienização para incremento das taxas de sucesso dos miniimplantes.

\section{Lesão de mucosa}

Para viabilizar a ativação ortodôntica através de dispositivos elásticos, molas ou fios de amarrilhos acoplados à cabeça do miniimplante, o posicionamento do mesmo muitas vezes apresenta-se saliente por palatino ou vestibular e pode gerar traumatismos e lesão de tecidos moles como a língua ou mucosa jugal (Fig. 43B).

O paciente deverá ser orientado a relatar desconfortos gerados pelos miniimplantes e o ortodontista avaliar o nível da lesão gerada, podendo optar, inclusive, pela remoção do recurso de ancoragem, caso necessário.

Dispositivos como cera ou resina de proteção 
para tecidos moles, poderão ser utilizados, transitoriamente, sobre a cabeça do miniimplante, na fase inicial da adaptação, como recurso preventivo.

\section{Lesão de raízes}

Devido às suas características, os miniimplantes ortodônticos são freqüentemente instalados entre raízes, tornando o procedimento arriscado, desde que não sejam obedecidos os critérios de planejamento e protocolo cirúrgico já citados.

Segundo Park ${ }^{44}$, as lesões causadas por perfurações radiculares intencionalmente geradas em animais, durante a cirurgia de instalação de miniimplantes, recuperaram-se completamente sem gerar maiores danos à vitalidade pulpar dos dentes lesados.

Entretanto, todos os cuidados fazem-se necessários para evitar este tipo de intercorrência, devido às possíveis implicações clínicas e legais geradas por esta complicação.

Sobretudo em instalações realizados na mandíbula, o cirurgião deverá estar atento, pois, devido à presença de uma cortical alveolar mais espessa, a sensibilidade táctil trans-cirúrgica, determinando a transição do tecido ósseo cortical para o medular, não é tão evidente quanto na maxila e assemelhase à consistência do tecido radicular. No entanto, Carano et al. ${ }^{6}$ afirmam que o contato do miniimplante ortodôntico com uma raiz aumentaria a resistência à inserção a ponto de pará-la.

Sugere-se ainda acompanhamento radiográfico periódico e teste de vitalidade pulpar para os casos onde forem detectados este tipo de complicação.

A figura 44 mostra uma radiografia panorâmica de um paciente com várias ausências dentárias. Imagina-se que não tenha havido uma programação cuidadosa de planejamento e instalação dos miniimplantes, o que culminou com trepanação da raiz de um pré-molar superior.

\section{Fratura do miniimplante}

De acordo com Carano ${ }^{6}$ e Kyung et al. ${ }^{28,29}$, a resistência dos miniimplantes supera a maioria das forças ortodônticas, não sendo a fratura um risco muito relevante durante a ativação, mas sim durante os procedimentos de inserção e remoção.

A fratura pode ocorrer durante a cirurgia de instalação, o que é mais freqüente, ou na remoção dos miniimplantes. Usualmente está relacionada ao excesso de pressão aplicada à chave longa de inserção manual ou à utilização de contra-ângulo com torque superior a $10 \mathrm{Ncm}^{37}$.

A densidade óssea aliada ou não à subperfuração pode influenciar sobremaneira na resistência ao torque de inserção, potencializando o risco de fratura da região próxima à cabeça do miniimplante.

Outro fator fundamental para minimizar o risco de fratura é a realização de movimentos cêntricos para inserção ou remoção do miniimplante ortodôntico, evitando-se torções ou momentos de força indesejáveis que gerariam uma concentração excessiva de forças em zonas específicas e possibilitariam a quebra do miniimplante (Fig. 45).

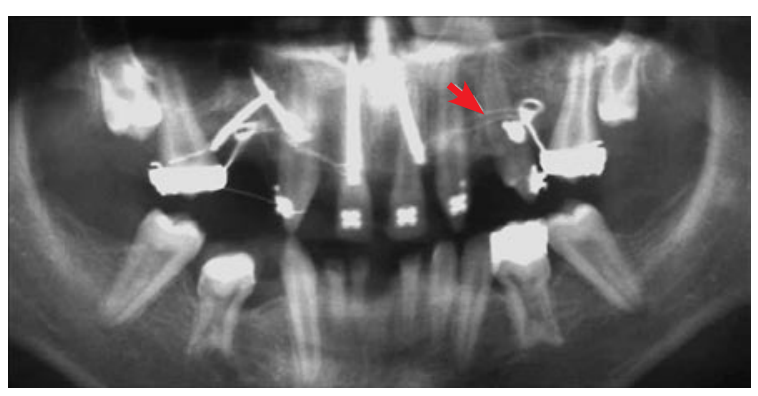

FIGURA 44 - Radiografia panorâmica ilustrando perfuração da raiz de um prémolar por miniimplante.

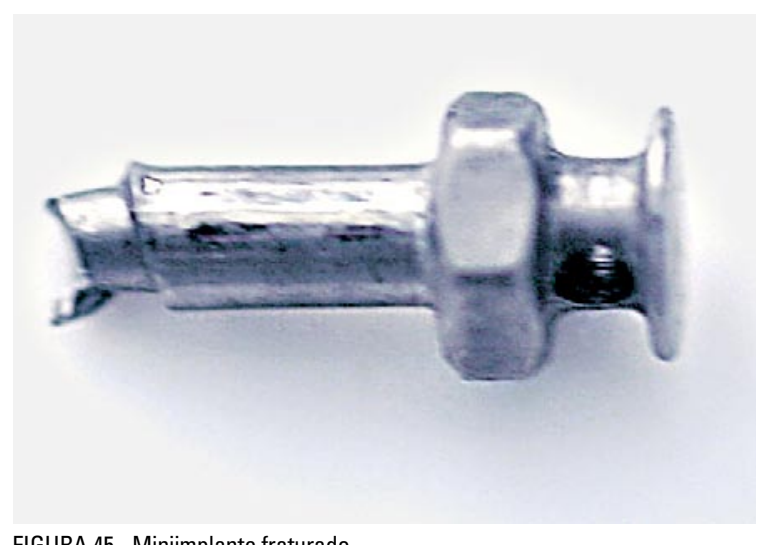

FIGURA 45 - Miniimplante fraturado. 

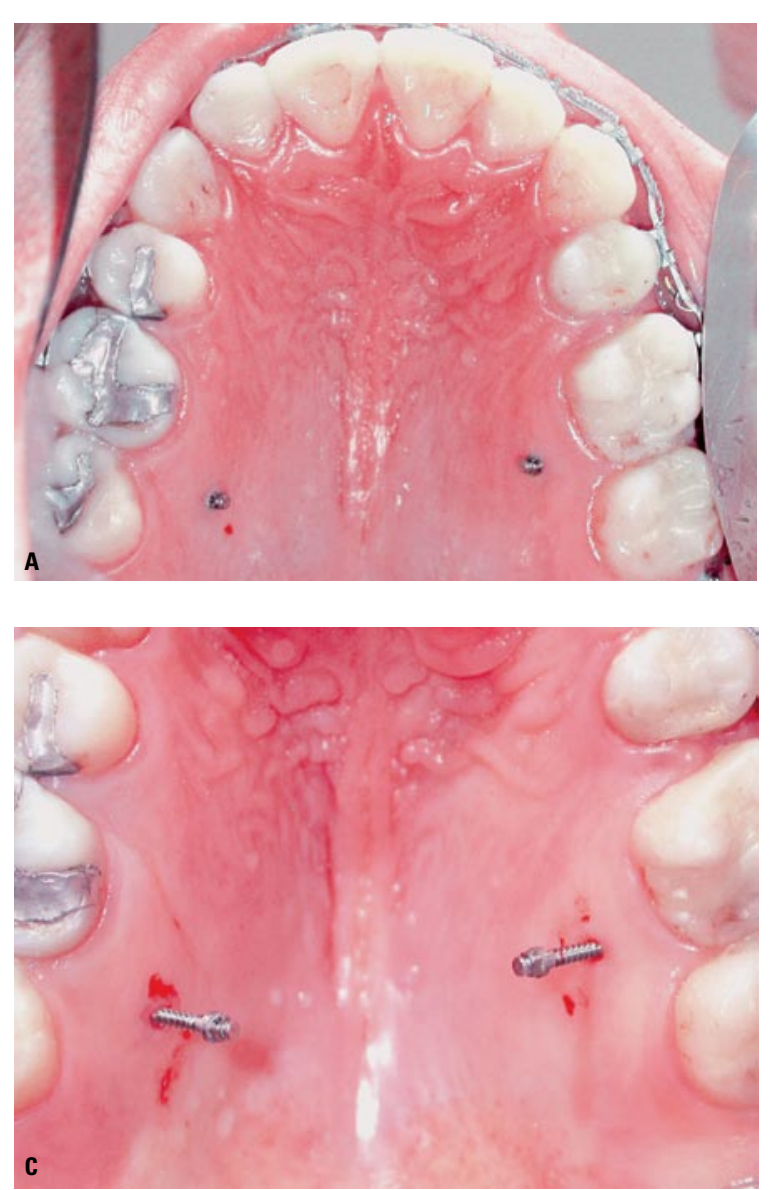

FIGURA 46 - Explantação de miniimplantes do palato: A) Após concluídas as ativações; B) início da remoção com a chave manual curta; C) Parcialmente removidos; D) Pequenos leitos deixados pelos miniimplantes.

Em caso de fratura, a remoção poderá ser realizada através da utilização de instrumentos manuais ou rotatórios delicados, sendo este um procedimento de difícil execução, porém necessário na maioria dos casos, já que a porção fraturada do parafuso poderia inviabilizar a continuidade do tratamento ortodôntico.

\section{EXPLANTAÇÃO}

Uma vez concluída sua função, os dispositivos transitórios de ancoragem deverão ser removidos com a utilização das mesmas chaves de inserção manual ou mecânica, em sentido inverso ao da instalação. Na grande maioria dos casos, não há necessidade de realização de anestesia no local ${ }^{36}$, sendo mínimo o desconforto reportado pelos pacientes.
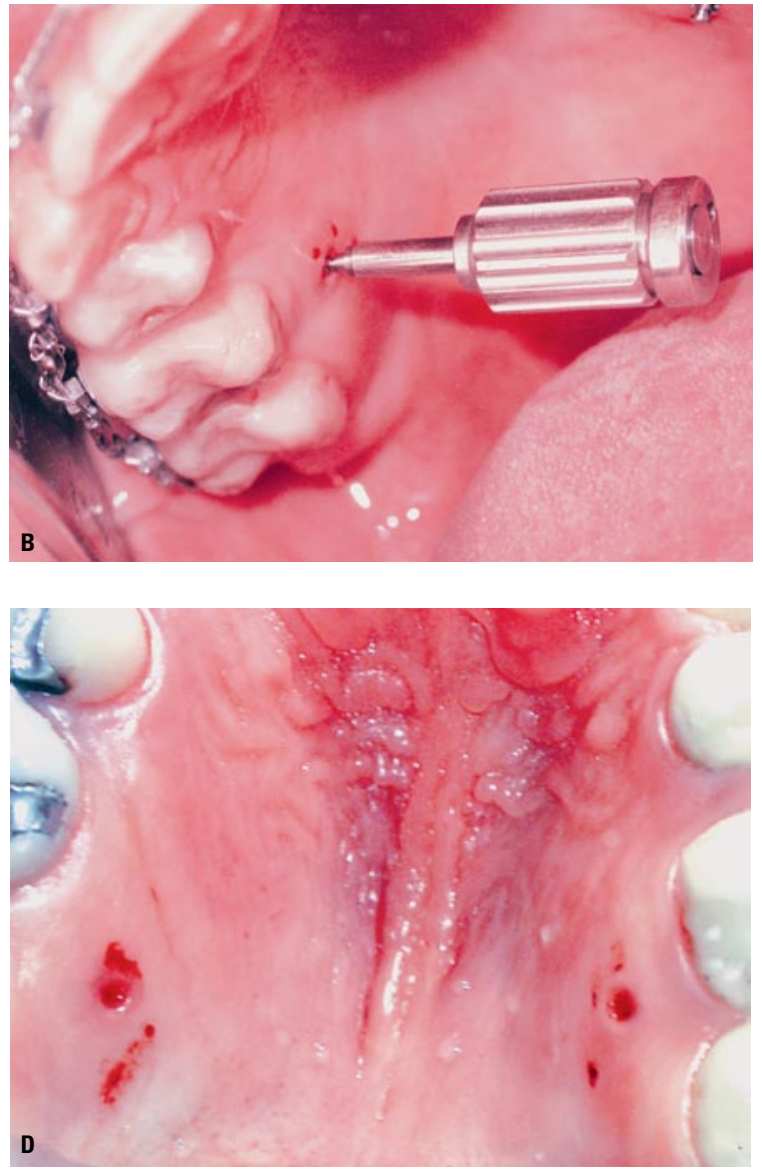

Torna-se desnecessária também a realização de procedimentos de sutura ou cuidados especiais, já que os leitos deixados pelos miniimplantes apresentarão cicatrização completa em pequeno espaço de tempo, devido às suas dimensões reduzidas. Para os pacientes com limiar de dor menor, ou áreas de tecido ósseo de maior densidade, poderá ser necessária a utilização de anestésico tópico ou mesmo infiltração anestésica subperiosteal, seguida de remoção dos implantes, sempre com o intuito de evitarem-se desconfortos para o paciente (Fig. 46).

\section{CONSIDERAÇÕES FINAIS}

A ancoragem esquelética proporciona um adequado controle de forças, tanto em magnitude quanto em direção. A utilização dos miniimplantes 
é recente na Ortodontia e tem-se mostrado extremamente promissora. Este recurso vem como uma opção a mais no tratamento ortodôntico, a fim de simplificar a mecânica e, em alguns casos, viabilizar a terapia, diminuindo o tempo de tratamento.

As possibilidades de posicionamento dos miniimplante e de movimentações dentárias durante sua utilização vão além das descritas neste artigo. Estas variações, porém, devem ser estudadas com cautela a fim de se evitar-se erros que venham a inviabilizar a função do miniimplante, ou ainda causar danos a estruturas anatômicas como raízes, vasos e nervos.

\section{AGRADECIMENTO}

Os autores agradecem à SempToshiba, pelo apoio constante ao Centro de Ortodontia e Ortopedia Facial Prof. José Édimo Soares Martins - FOUFBA.

\title{
Skeletal anchorage in Orthodontics with mini-implants
}

\begin{abstract}
Temporary anchorage devices, such as mini-implants, have been widely used over the last few years. These devices are very important where anchorage is a major factor for the successful outcome of orthodontic treatment. The authors will comment on the broader aspects of orthodontic treatment with application of mini-implants, choice of implant sites, discussing their indications, surgical procedures, post-surgical oral hygiene care and the most frequent complications.
\end{abstract}

Key words: Mini-implants. Micro-screws. Anchorage. Orthodontics.

\section{REFERÊNCIAS}

1. ASK US. Am J Orthod Dentofacial Orthop, St. Louis, v. 121, no. 2, Feb. 2004.

2. $B A E, S$. M. Clinical application of micro-implant anchorage. J Clin Orthod, Boulder, v. 36, no. 5, p. 298-302, May 2002.

3. BAE, S. M.; KYUNG, H. M. Mandibular molar intrusion with miniscrew anchorage. J Clin Orthod, Boulder, v. 40, no. 2, p. 107-108, Feb. 2006.

4. BEZERRA, F. et al. Ancoragem absoluta utilizando microparafusos ortodônticos de titânio. Planejamento e protocolo cirúrgico (Trilogia - Parte I). Implant News, São Paulo, v. 1, n. 6, p. 469-475, nov./dez. 2004.

5. BLOCK, M. S.; HOFFMAN, D. R. A new device for absolute anchorage for orthodontics. Am J Orthod Dentofacial Orthop, St. Louis, v. 107, no. 3, p. 251-258, Mar. 1995.

6. CARANO, A. et al. Clinical applications of the miniscrews anchorage system. J Clin Orthod, Boulder, v. 39, no. 1, p. 9-42, Jan. 2005.

7. CELENZA, F.; HOCHMAN, M. N. Absolute anchorage in orthodontics: direct and indirect implant-assisted modalities. J Clin Orthod, Boulder, v. 34, no. 7, p. 397-402, July 2000.

8. CHENG, S. et al. A prospective study of the risk factors associated with failure of mini-implants used for orthodontic anchorage. Int J Oral Maxillofacial Implants, Lombard, v. 19, no. 1, p. $100-106,2004$.

9. CHUNG, K.; KIM, S. H.; KOOK, Y. C. Orthodontic microimplant for distalization of mandibular dentition in Class III correction. Angle Orthod, Appleton, v. 75, no. 1, p. 119-128, 2005.

10. CHUNG, K. R.; KIM, S. H.; KOOK, Y. A. The C-Orthodontic micro-implant. J Clin Orthod, Boulder, v. 38, no. 9, p. 478-486, Sept. 2004.

11. CORNELIS, M. A.; CLERCK, H. J. D. Biomechanics of skeletal anchorage. Part 1 Class II extraction treatment. J Clin Orthod,
Boulder, v. 40, no. 4, p. 261-269, Apr. 2006

12. COSTA, A.; RAFFAINI, M.; MELSEN, B. Miniscrews as orthodontic anchorage: a preliminary report. Int J Adult Orthod Orthognath Surg, Lombard, v. 13, no. 3, p. 201-209, 1998.

13. COUSLEY, R. Critical aspects in the use of orthodontic palatal implants. Am J Orthod Dentofacial Orthop, St. Louis, v. 127, no. 6, p. 723-729, June 2005.

14. DEVINCENZO, J. P. A new non-surgical approach for treatment of extreme dolicocephalic malocclusions. Part 1 Appliance design and mechanotherapy. J Clin Orthod, Boulder, v. 40, no. 3, p. 161-170, Mar. 2006.

15. DEVINCENZO, J. P. A new non-surgical approach for treatment of extreme dolicocephalic malocclusions. Part 2. Case selections and management. J Clin Orthod, Boulder, v. 40, no. 4, p. 250-260, Apr. 2006.

16. ERVERDI, N.; TOSUN, T.; KELES, A. A new anchorage site for the treatment of anterior open bite: zygomatic anchorage. Case report. World J Orthod, Carol Stream, v. 3, no. 2, p. 147-153, 2002.

17. ERVERDI, N.; USUMEZ, S.; SOLAK, A. New generation open bite treatment with zygomatic anchorage. Angle Orthod, Appleton, v. 76, no. 3, p. 519-526, 2006.

18. FABER, J.; BERTO, P. M.; ANCHIETA, M.; SALES, F. Tratamento da mordida aberta anterior com ancoragem em miniplacas de titânio. Rev Dental Press Estética, Maringá, v. 1, n. 1, p. 87-100, 2004.

19. FAVERO, L.; BROLLO, P.; BRESSAN, E. Orthodontic anchorage with specific fixtures: related study analysis. Am J Orthod Dentofacial Orthop, St. Louis, v. 122, no. 1, p. 84-94, July 2002.

20. FRITZ, U.; EHMER, A.; DIEDRICH, P. Clinical suitability of titanium microscrews for orthodontic anchorage: preliminary experiences. J Orofac Orthop, München, v. 65, no. 5, p. 410-418, 2004.

21. GELGÖR, I. E. et al. Intraosseous screw: supported upper molar distalization. Angle Orthod, Appleton, v. 74, no. 6, p. 836-848, 2004. 
22. GIANCOTTI, A et al. Miniscrew treatment of ectopic mandibular molars. J Clin Orthod, Boulder, v. 37, no. 7, p. 380-383, July 2003.

23. GRAY, J.B.; SMITH, R. Transitional implants for orthodontic ancorage. J Clin Orthod, Boulder, v. 34, no. 11, p. 659-666, Nov. 2000.

24. HIGUCHI, K. W.; SLACK, J. M. The use of titanium fixtures for intraoral anchorage to facilitate orthodontic tooth movement. Int J Oral Maxillofac Implants, Lombard, v. 6, no. 3, p. 338-344, 1991.

25. JANSSENS, F. et al. Use of an onplant orthodontic anchorage. Am J Orthod Dentofacial Orthop, St. Louis, v. 122, no. 5, p. 566-570, Nov. 2002

26. KANOMI, R. Mini-implant for orthodontic anchorage. J Clin Orthod, Boulder, v. 31, no. 11, p. 763-767, Nov. 1997.

27. KIM, J. H.; AHN, S. J.; CHANG, Y. I. Histomorfometric and mechanical analyses of the drill-free screw as orthodontic anchorage. Am J Orthod Dentofacial Orthop, St. Louis, v. 128, no. 2, p.190-194, Aug. 2005.

28. KYUNG, H. M. et al. Development of orthodontic micro-implants for intraoral anchorage. J Clin Orthod, Boulder, v. 37, no. 6, p. 321-328, June 2003.

29. KYUNG, H. M. et al. Handbook for the Absoranchor Orthodontic Micro-implant. 3 rd ed. [S.I.: s.n.], 2004.

30. KYUNG, S. H.; CHOI, J. H.; PARK, Y. C. Miniscrew anchorage used to protract lower second molars into first molar extraction sites. J Clin Orthod, Boulder, v. 37, no. 10, p. 575-579, Oct. 2003.

31. KYUNG, S. H.; HONG, S. G.; PARK, Y. C. Distalization of maxillary molars with a midpalatal miniscrew. J Clin Orthod, Boulder, v. 37, no. 1, p. 22-26, Jan. 2003.

32. LABOISSIĖRE JÚNIOR, M. et al. Ancoragem absoluta utilizando microparafusos ortodônticos. Protocolo para aplicação clínica (Trilogia - Parte II). Implant News, São Paulo, v. 2, n. 1, p. 37-46, jan./fev. 2005.

33. LABOISSIÈRE JÚNIOR, M. et al. Ancoragem absoluta utilizando microparafusos ortodônticos: complicações e fatores de risco (Trilogia - Parte III). Implant News, São Paulo, v. 2, n. 2, p. 165-168, mar./abr. 2005

34. LEE, J. S. Micro-implant anchorage for lingual treatment of a skeletal Class II malocclusion. J Clin Orthod, Boulder, v. 35, no. 10, p. 643-647, Oct. 2001

35. LIOU, E. J. W.; PAI, B. C. J.; LIN, J. C. Y. Do miniscrews remain stationary under orthodontic forces? Am J Orthod Dentofacial Orthop, St. Louis, v. 126, no. 1, p. 42-47, July 2004

36. MAH, J.; BERGSTRAND, F. Temporary anchorage devices: a status report. J Clin Orthod, Boulder, v. 39, no. 3, p. 132-136, Mar. 2005.

37. MARASSI, C. et al. O uso de miniimplantes como auxiliares do tratamento ortodôntico. Ortodontia SPO, São Paulo, v. 38, n. 3, p. 256-265, jul./set. 2005

38. MASIOLI, D. L. C.; ALMEIDA, M. A. O.; BATITTUCC, E.; MEDEIROS, P. J. Intrusão ortodôntica de molares utilizando mini-placas e parafusos de titânio. R Clin Ortodon Dental Press, Maringá, v. 4 , n. 5 , p. 81-87, out./nov. 2005

39. MIYAWAKI, S. et al. Factors associated with the stability of titanium screw placed in the posterior region for orthodontic anchorage. Am J Orthod Dentofacial Orthop, St. Louis, v. 124, no. 4 , p. 373-378, Oct. 2003

40. MOREA, C.; et al. Surgical guide for optimal positioning of miniimplants. J Clin Orthod, Boulder, v. 39, no. 5, p. 317-321, May 2005.

41. NASCIMENTO, M. H. A.; ARAÚJO, T. M.; BEZERRA, F. Microparafuso ortodôntico: instalação e protocolo de higiene periimplantar. R Clin Ortodon Dental Press, Maringá, v. 5, n. 1, fev./mar., p. 24-43, 2006

42. PAIK, C.: WOO, Y: BOYD, R. Treatment of an adult patient with vertical maxillary excess using miniscrew fixation. J Clin Orthod, Boulder, v. 37, no. 8, p. 423-428, Aug. 2003

43. PARK, H. S. An anatomical study using $C T$ images for the implantation of micro-implants. Korea J Orthod, [S. I.], v. 32, no. 6, p. 435-441, 2002
44. PARK, H. S. Intrusión molar con anclaje de microimplantes (MIA Micro-Implant Anchorage). Ortodoncia clinica, Buenos Aires, v. 6, n. 1, p. 31-36, 2003

45. PARK, H. S.; KWON, O. W.; H. M.; SUNG, J. H. Micro-implante anchorage for forced eruption of impacted canines. J Clin Orthod, Boulder, v. 38, no. 5, p. 297-302, May 2004.

46. PARK, H. S.; KWON, O. W.; SUNG, J. H. Microscrew implant anchorage sliding mechanics. World J Orthod, Carol Stream, v. 6, n. 3, p. 265-274, 2005

47. PARK, H. S.; KWON, O. W.; SUNG, J. H. Uprighting second molars with micro-implant anchorage. J Clin Orthod, Boulder, v. 38, no. 2, p. 100-103, Feb. 2004

48. PARK, H. S.; KWON, T. G. Sliding mechanics with microscrew implant anchorage. Angle Orthod, Appleton, v. 74, no. 5 p. 703-710, Oct. 2004

49. PARK, H. S.; KWON, T. G.; SUNG, J. H. Nonextraction treatment with microscrew implants. Angle Orthod, Appleton, v. 74 no. 4 , p. 539-549, Aug. 2004

50. POGGIO, P. M. et al. "Safe Zones": a guide for miniscrew positioning in the maxillary and mandibular arch. Angle Orthod Appleton, v. 76, no. 2, p. 191-197, 2006

51. POSTERMAN, B. et al. Am J Orthod Dentofacial Orthop, St. Louis, v. 107, no. 3, p. 245-250, Mar. 1995.

52. ROBERTS, W. E. et al. Rigid endosseous implants for orthodontic and orthopedic anchorage. Angle Orthod, Appleton, v. 59, no. 4, p. 247-256, Dec. 1989

53. SCHNELLE, M. A. et al. A radiographic evaluation of the availability of bone for placement of miniscrews. Angle Orthod, Appleton, v. 74, no. 6, p. 830-835, 2004

54. SHERWOOD, K. H.; BURCH, J. G.; THOMPSON, J. Closing anterior open bite by intruding molars with titanium miniplate anchorage. Am J Orthod Dentofacial Orthop, St. Louis, v. 122, no. 6. p. $593-600,2002$

55. SOUTHARD, T. E. et al. Intrusion anchorage potential of teeth versus implants. Am J Orthod Dentofacial Orthop, St. Louis, v. 107, no. 2, p. 115-120, Feb. 1995

56. SUGAWARA, J. et al. Distal movement of mandibular molars in adult patient with skeletal anchorage system. Am J Orthod Dentofacial Orthop, St. Louis, v. 125, no. 2, p. 130-138, Feb. 2004

57. SUZUKI, E. Y.; BURANASTIDPORN, B. An adjustable surgical guide for miniscrew placement. J Clin Orthod, Boulder, v. 39, no. 10, p. 588-590, Oct. 2005.

58. TURLEY, P. K. et al. Orthodontic force application to titanium endosseous implant. Angle Orthod, Appleton, v. 58, no. 2 p. 151-162, Apr. 1988.

59. UMEMORI, M. et al. Skeletal anchorage system for open-bite correction. Am J Orthod Dentofacial Orthop, St. Louis, v. 115, no. 2, p. 166-174, 1999.

60. VILLELA, H. et al. Utilização de miniimplantes para ancoragem ortodôntica direta. Innovations J, Nova Scotia, v. 8, no. 1 p. 5-12, 2004.

61. WEHRBEIN, H.; DIEDRICH, P. Endosseous titanium implants during and after orthodontic load: an experimental study in the dog. Clin Oral Implants Res, Copenhagen, v. 4, no. 2, p. 76-82, June 1993

62. WEHRBEIN, H.; FEIFEL, H.; DIEDRICH, P. Palatal implant anchorage reinforcement of posterior teeth: a prospective study. Am J Orthod Dentofacial Orthop, St. Louis, v. 116, no. 6 p. 678-686, Dec. 1999

\section{Endereço de correspondência}

Telma Martins de Araújo

Centro de Ortodontia e Ortopedia Facial

Prof. José Édimo Soares Martins - FO.UFBA.

Av. Araújo Pinho, 62/7 andar - Canela

CEP: 40110-912 - Salvador - BA

tmatelma@globo.com 